\title{
Shining a light on the composition and distribution patterns of mesophotic and subphotic fish communities in Hawai'i
}

\author{
Mariska Weijerman ${ }^{1, *}$, Arnaud Grüss ${ }^{2}$, Dayton Dove ${ }^{3,4}$, Jacob Asher $^{4}$, \\ Ivor D. Williams ${ }^{1}$, Christopher Kelley ${ }^{5}$, Jeffrey C. Drazen ${ }^{5}$ \\ ${ }^{1}$ NOAA Pacific Islands Fisheries Science Center, Honolulu, HI 96818, USA \\ ${ }^{2}$ School of Aquatic and Fishery Sciences, University of Washington, Box 355020, Seattle, WA 98105-5020, USA \\ ${ }^{3}$ British Geological Survey, Edinburgh EH14-4AP, UK \\ ${ }^{4}$ Joint Institute of Marine and Atmospheric Research, University of Hawaii at Manoa, Honolulu, HI 96822, USA \\ ${ }^{5}$ Department of Oceanography, University of Hawaii at Manoa, Honolulu, HI 96822, USA
}

\begin{abstract}
As agencies shift from single-species management to ecosystem-based fisheries management, ecosystem models are gaining interest for understanding species dynamics in relation to oceanographic and ecological processes and human marine uses. However, information on community structure or distribution of many species that occupy deep ( $>30 \mathrm{~m}$ ) waters is largely unavailable. We amassed a total of 24686 fish observations of 523 species/taxa for the $30-410 \mathrm{~m}$ depth areas surrounding the main Hawaiian Islands (MHI). We also obtained estimates of geomorphological variables, including substrate type, slope, rugosity, and ridge-like features. Using these 2 data sources, we (1) identified distinct fish communities along the 30-410 m depth gradient, and (2) generated relative biomass maps for fish functional groups. We showed that the mesophotic zone ranges between 30 and $129 \mathrm{~m}$, with a fish faunal break at $60 \mathrm{~m}$. Beyond this zone, 4 subphotic zones were identified: upper rariphotic (130-169 m), mid-rariphotic (170-239 m), lower rariphotic (240-319 m), and upper bathyal (320-410 m). We assigned fish species to functional groups partly based on identified depth ranges and fitted general additive models (GAMs) integrating geomorphological covariates to the functional group relative biomass estimates to determine the environmental variables that best predict the probability of encounter and relative biomass of each fish functional group. Finally, GAM predictions were employed to map functional group relative biomass distributions. These distribution maps showed a high relative biomass of many groups in the center of the MHI chain. This study contributes to a better understanding of fish community structure around the MHI and will inform ecosystem model parameterization.
\end{abstract}

KEY WORDS: Coral reef ecosystems $\cdot$ Mesophotic zone $\cdot$ Subphotic zone $\cdot$ Mesophotic coral ecosystems $\cdot$ Community structure $\cdot$ Generalized additive models $\cdot$ Spatial distribution maps $\cdot$ Fish

\section{INTRODUCTION}

Interest in ecosystem-based fisheries management (EBFM) is increasing worldwide, including in the main Hawaiian Islands (MHI) region (e.g. Pikitch et al. 2004, Harvey et al. 2017). EBFM takes into consideration the effects of physical habitat features and

${ }^{*}$ Corresponding author: mariska.weijerman@noaa.gov abiotic environmental drivers on species dynamics, trophic interactions, and interactions between marine species and human activities (Link \& Browman 2014, Weijerman et al. 2016, Gullestad et al. 2017). Ecosystem models are valuable EBFM tools, as they can simulate relationships among drivers, pressures, and resulting ecosystem states and quantify trade-

(C) The authors 2019. Open Access under Creative Commons by Attribution Licence. Use, distribution and reproduction are unrestricted. Authors and original publication must be credited. 
offs in ecosystem services under different management and environmental scenarios (Plagányi 2007, Nelson et al. 2009, Weijerman et al. 2015, Grüss et al. 2017). For example, the sophistication and inclusiveness of the spatially explicit 'Atlantis' ecosystem modeling platform (Fulton et al. 2004) make it well adapted to address a wide range of EBFM questions (Kaplan et al. 2010, Fulton et al. 2014, Weijerman et al. 2015). Trophic interactions in ecosystem models strongly depend on the way species groups' biomasses are allocated spatially, as species' group distributions condition patterns of spatial overlap among predators, prey, and competitors (Grüss et al. 2016). For example, feeding migrations result in an exchange of energy and nutrients between different depth zones, as well as between trophic levels in the horizontal dimension (Steinberg et al. 2008, Papastamatiou et al. 2015, Gloeckler et al. 2018). Therefore, approaches estimating species groups' vertical and horizontal distributions are critically needed. However, in tropical regions like the MHI region, information on horizontal and vertical distributions is often lacking for non-commercial fish species and fish species that primarily occur outside of the shallow inshore areas that have been most intensively surveyed.

The widespread decline of shallow-water coral reef ecosystems in recent decades (De'ath et al. 2012) has led to increased focus on coral reef ecosystems occurring at 30-150 m depth where light-dependent species are still present (herein referred to as 'mesophotic' or 'mesophotic coral ecosystems,' MCEs). Some studies suggest that MCEs have the potential to function as deep reef refugia for shallow-water generalist spe- cies (benthic invertebrates and fishes) (Slattery \& Lesser 2012, Lindfield et al. 2014, Pereira et al. 2018) or thermally sensitive species (Frade et al. 2018). Other studies challenge the deep reef refugia hypothesis, indicating that mesophotic communities retain their own distinct depth ranges, with little holistic overlaps with shallow reefs (Bongaerts et al. 2010, Rocha et al. 2018). Much more limited information is available on the structure of fish communities with depth in the much darker habitats located at 150-400 m depth (herein referred to as the 'subphotic zone'). However, a recent Caribbean study (Baldwin et al. 2018) identified 2 faunal breaks in the subphotic zone (termed the 'rariphotic zone' in that study), suggesting that further fish community zonation is likely.

The increased interest in MCEs is also true for the MHI region. The occurrence of MCEs in the MHI region has been related to water temperature, light transmission, and the seafloor habitat (Rooney et al. 2010, Costa, et al. 2015, Pyle et al. 2016). Faunal breaks have been found at $\sim 60$ and $\sim 90 \mathrm{~m}$, as well as a decrease in abundance, diversity, and biomass with depth within the mesophotic zone and a higher number of endemic species in the lower mesophotic zone compared to the upper mesophotic zone (Pyle et al. 2016, Asher et al. 2017). As light fades with increasing depth (Fig. 1A), there are also shifts in community composition when transitioning from the upper to the lower mesophotic zone, with herbivorous fishes becoming less numerous and planktivorous fishes providing a larger proportional contribution to fish communities (Fukunaga et al. 2016, Pyle et al. 2016, Asher et al. 2017). Apart from light, tempera-
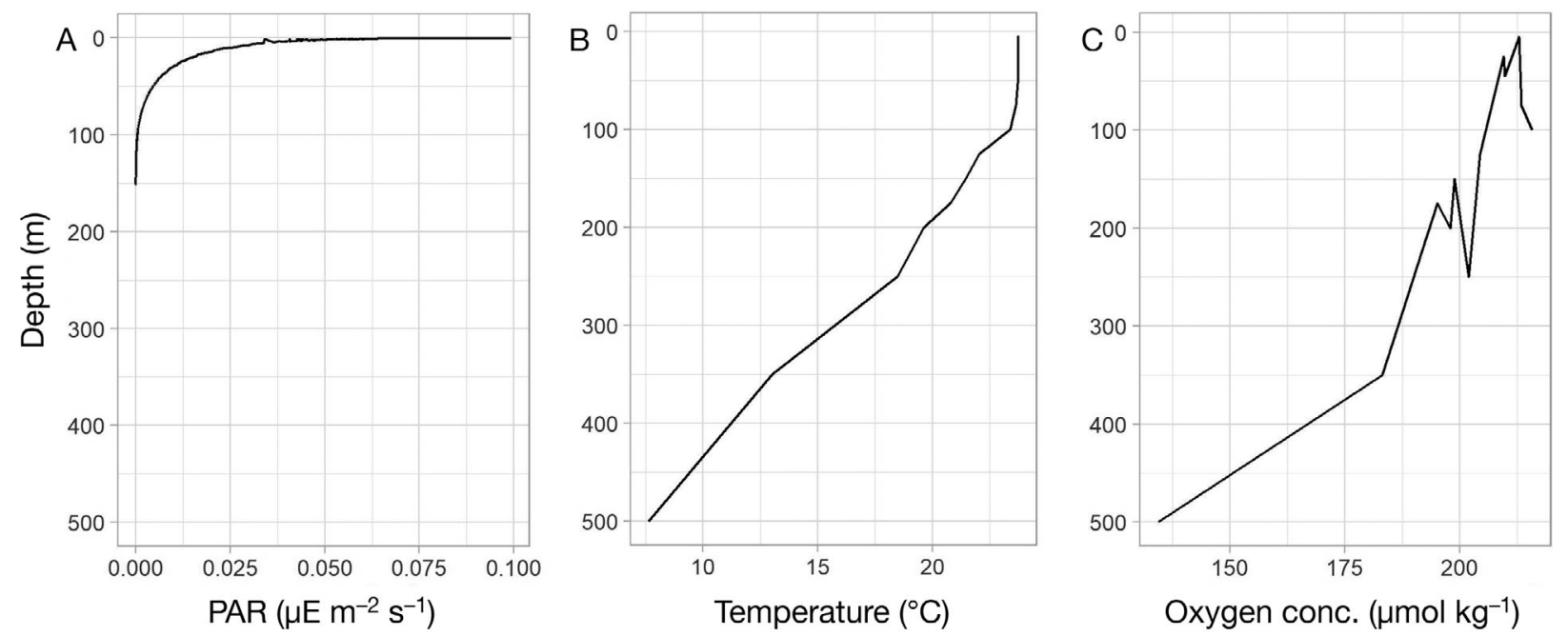

Fig. 1. Changes in environmental variables along a depth gradient measured at Station Aloha northeast of Honolulu, Hawai'i (data source: http://hahana.soest.hawaii.edu/hot/hot_jgofs.html), showing (A) available light for photosynthesis (photosynthetically active radiation, PAR), (B) temperature, and (C) oxygen concentration 
ture and oxygen concentration also decrease with depth, making depth an important 'umbrella' variable for quantifying faunal changes (Fig. 1B,C). The general decrease in fish abundance and species diversity from shallow to mesophotic depth is thought to continue into deeper habitats (Chave \& Mundy 1994, Parrish 2006). However, faunal community characteristics in the subphotic zone around the MHI remain largely unknown. Research at subphotic depths in the MHI region has been mainly driven by interest in the distribution and abundance of commercially important bottomfishes consisting of 6 deepwater snappers (Lutjanidae) and 1 grouper (Epinephelidae), which are collectively referred to as the 'Deep-7 bottomfish complex' or 'Deep-7' (Moore et al. 2013, Oyafuso et al. 2017). A few other deep-water MHI studies have focused on precious corals (Parrish 2006, Rooney et al. 2010) and 'species of interest' such as marine mammals (Benoit-Bird \& Au 2003, Weijerman et al. 2017).

Globally, seabed morphology and composition are frequently found to be useful proxies for the distribution and abundance of benthic organisms and other associated communities (e.g. Clark et al. 2010, McArthur et al. 2010). For example, benthopelagic fishes (such as groupers, eels, and scorpion fishes, that swim above the seafloor and feed on both benthic and free-swimming organisms but remain associated with benthic substrates) are often found along seafloor features where currents or upwelling form (e.g. seamounts and escarpments). In the MHI region, as elsewhere, maps of mesophotic or subphotic habitats are either absent or insufficiently accurate to adequately support large-scale ecosystem research and marine spatial planning (Costa et al. 2015). While seafloor habitats are generally observed to transition from hard-bottom at $\sim 20-30 \mathrm{~m}$ depth (associated with shallow fringing reefs) to greater proportions (and larger provinces) of soft-bottom/unconsolidated sediment in deeper zones (Rooney et al. 2010), the geomorphology and composition of the seafloor at mesophotic depths is geographically variable and complex, and cannot be linked to depth strata alone. To remedy the lack of geomorphological estimates for the MHI region, Dove et al. (2019) developed a novel classification approach around the MHI to define the substrate as hard or soft, depending on several bathymetric derivatives (e.g. slope), as well as acoustic backscatter in coral reef and deeperwater environments from 0-500 $\mathrm{m}$ depth. The presence of hard substrates was found to vary according to a range of geological (e.g. submerged lava flows) and oceanographic factors (e.g. locally high currents preventing sedimentation over hard ground). Hard substrates associated with high slopes were also found to be commonly associated with fossil reefs or karst features, yet the depths of these features differed between islands due to variable seamount subsidence rates across the MHI region (Dove et al. 2019).

To improve understanding of the Hawaiian mesoand subphotic fish communities, we compiled and analyzed a spatially continuous seafloor dataset and a large survey dataset. The objectives of this study were to: (1) identify fish community structure in the vertical dimension, and (2) generate relative biomass distribution maps for the fish functional groups (i.e. groups of fish species with similar diets, life-history traits, and habitat preferences) that can be used to parameterize the biological component of the Atlantis ecosystem model for the MHI to support EBFM in the region (Supplement 1 in the supplementary material at www.int-res.com/articles/suppl/ m630p161_supp.pdf).

\section{MATERIALS AND METHODS}

\subsection{Study site}

Our study region consists of the 30-400 m depth areas around 8 of the MHI stretching across a $650 \mathrm{~km}$ SE-NW gradient between $19^{\circ} \mathrm{N}, 155^{\circ} \mathrm{W}$ and $22^{\circ} \mathrm{N}$, $160^{\circ} \mathrm{W}$ (Fig. 2). All 8 islands are volcanic islands located in the oligotrophic (nutrient-poor) subtropical gyre of the North Pacific. The ocean is characterized by water temperatures of around $25^{\circ} \mathrm{C}$ at the surface $(0-30 \mathrm{~m})$ with temperatures of around $23^{\circ} \mathrm{C}$ at $50 \mathrm{~m}$ after which it gradually declines to $7^{\circ} \mathrm{C}$ at $400 \mathrm{~m}$ (Fig. 1). Salinity and oxygen vary minimally in these 0-400 $\mathrm{m}$ water depths and are around $35 \mathrm{ppt}$ and $200 \mu \mathrm{mol} \mathrm{O} \mathrm{kg}^{-1}$, respectively (Fig. 1). Due to the clarity of the water, light penetrates to about 100$150 \mathrm{~m}$ depth. Decadal changes are driven by the North Pacific Gyre Oscillation that respond to regional and basin-scale variations in wind-driven upwelling and horizontal advection (Di Lorenzo et al. 2008).

\subsection{Survey data}

Data came from 5 programs using different survey methods (Table 1 ). We very briefly describe these methods and refer the reader to the papers cited below for details. Our data sources were:

(1) Baited remote underwater stereo video systems used by the Pacific Islands Fisheries Science Center 


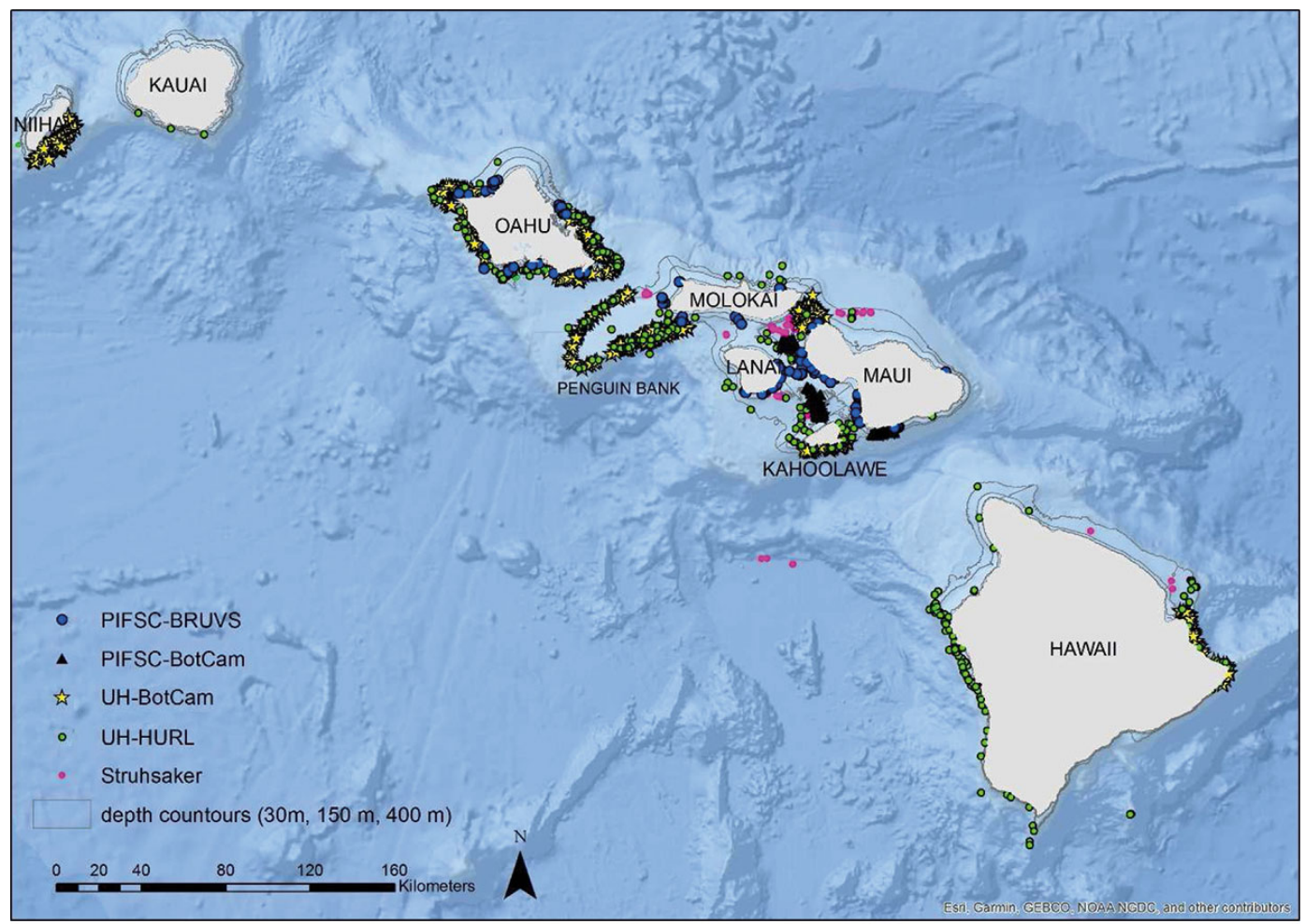

Fig. 2. Study region, showing the stations surveyed by the different survey programs considered in this study. See Table 1 for definitions of abbreviations and additional information on the programs

('PIFSC-BRUVS'). Sites were randomly selected per depth $(0-30,30-100 \mathrm{~m})$ and habitat (hard/soft) strata from $500 \times 500 \mathrm{~m}$ grid cell center points within the $100 \mathrm{~m}$ depth contour of the islands of $\mathrm{O}^{\prime} \mathrm{ahu}$ and Maui-Nui (the islands of Moloka'i, Lana'i, Kaho'olawe, and Maui) and were located at least $500 \mathrm{~m}$ apart from each other. Sony handycams (CX-7 and CX-12) were calibrated using the CAL software (SeaGIS). Each BRUVS was baited and deployed for
$60 \mathrm{~min}$. From the footage, species-level relative abundance, defined as the maximum number of each species observed in a single frame during the entire video (MaxN; Ellis \& DeMartini 1995), was estimated using the program 'EventMeasure-Stereo' (SeaGIS). More information can be found in Asher et al. (2017).

(2) Bottom camera bait stations deployed by the PIFSC ('PIFSC-BotCam'). Sites were randomly selected per depth $(75-200,200-300,300-400 \mathrm{~m})$ and

Table 1. Characteristics of the survey data considered in this study. PIFSC: Pacific Islands Fisheries Science Center; HURL: Hawai'i Underwater Research Laboratory; UH: University of Hawai'i; BRUVS: baited remote underwater video system; BotCam: bottom camera bait station

\begin{tabular}{|c|c|c|c|c|}
\hline Source & $\begin{array}{l}\text { Survey type, } \\
\text { depth range }(\mathrm{m})\end{array}$ & $\begin{array}{l}\text { Sampling } \\
\text { time frame }\end{array}$ & $\begin{array}{l}\text { Number of } \\
\text { observations }\end{array}$ & $\begin{array}{c}\text { Number of surveys (total area surveyed } \\
\text { or total survey time) and zone }\end{array}$ \\
\hline PIFSC-BRUVS & Video, 30-100 & 2012-2013 & 728 & 66 (66 h), mesophotic \\
\hline PIFSC-BotCam & Video, 60-310 & 2011-2013 & 896 & $\begin{array}{l}129(96.8 \mathrm{~h}), \text { mesophotic } \\
211(158.3 \mathrm{~h}), \text { subphotic }\end{array}$ \\
\hline UH-BotCam & Video, 30-320 & 2008-2011 & 1560 & $\begin{array}{l}185(138.8 \mathrm{~h}), \text { mesophotic } \\
698(523.5 \mathrm{~h}) \text {, subphotic }\end{array}$ \\
\hline UH-HURL & Submarine, $37-400$ & 1985-2016 & 18366 & $\begin{array}{l}237\left(1.46 \mathrm{~km}^{2}\right) \text {, mesophotic } \\
432\left(2.74 \mathrm{~km}^{2}\right) \text {, subphotic }\end{array}$ \\
\hline Struhsaker (1973) & Trawls, $30-400$ & $1967-1968$ & 3236 & $\begin{array}{l}72\left(3.84 \mathrm{~km}^{2}\right) \text {, mesophotic } \\
141\left(7.52 \mathrm{~km}^{2}\right) \text {, subphotic }\end{array}$ \\
\hline
\end{tabular}


habitat (hard/soft; high/low slope) strata from $50 \times$ $50 \mathrm{~m}$ grid cell center points in the 75-400 $\mathrm{m}$ depth range in the Maui-Nui region. At each site, a baited stationary stereo-video camera was deployed for 45 min. This BotCam system was developed by the PIFSC in collaboration with the University of Hawai'i, Hawai'i Undersea Research Laboratory (UH HURL) and uses ultralow-light video cameras (Monochrome Navigator, Remote Ocean Systems; Merritt et al. 2011). Cal software was used to calibrate the camera, and the software EventMeasure (SeaGIS) was used to annotate species from video footage and to measure fork length (in mm) for each fish. The MaxN metric was used as the basis for relative abundance estimations. More information can be found in Richards et al. (2016) and Ault et al. (2018).

(3) BotCams deployed by the University of Hawai'i at Manoa (UH) Drazen laboratory ('UH-BotCam'). Sites were randomly selected per habitat (hard/soft; high/low slope) strata from $200 \mathrm{~m}^{2}$ grid cells in the 90-310 m depth range around all the MHI and were located at least $400 \mathrm{~m}$ apart from each other. At each site, a BotCam was deployed for $45 \mathrm{~min}$. Cal software was used to calibrate the camera, and the software EventMeasure (SeaGIS) was used to annotate species from video footage. The MaxN metric was used as the basis for relative abundance estimation. More information can be found in Moore et al. (2013) and Sackett et al. (2014).

(4) Manned submersibles employed by the UHHURL. Submersible dives were conducted during the day (08:30-16:30 h) and at night (19:00-02:00 h) around all MHI. We aggregated the data collected for various studies, hence no specific sample design is valid for all surveys, and various cameras were used. In general, fish counts were made along a transect line (a continuous recording of $30 \mathrm{~min}$ at a constant speed of 2 knots and an average elevation of $2 \mathrm{~m}$ above the substrate) at different depths and included all habitat types (hard, soft, slope, and flat). Two observers (starboard and port windows) counted all visible fish species in 2 non-overlapping fields of view, each spanning about $15 \mathrm{~m}$. Data were recorded on audio tracks of the digital video camera systems along with the submersible's GPS positions and depth at 10 min intervals. In the laboratory, observer counts of each species were extracted from the recordings and noted as categorical quantities with latitude, longitude, and depth in the HURL database. More information can be found in Vetter et al. (2010).

(5) Trawl surveys conducted by UH Department of Zoology (Struhsaker 1973). Shrimp bottom trawls (12.5 $\mathrm{m}$ beam) were conducted during the day and at night around Maui Nui and off the northwest coast of O'ahu and Hawai'i in the 61-850 m depth range that were deemed 'trawlable,' i.e. flat with unconsolidated bottom. The sampled area (in hectares) was calculated based on on-bottom GPS locations and the average sampling width of the trawl. Upon retrieval, fish were identified to species level and their numbers recorded. Reported in tables are the total numbers and numbers per hectare per sampling site, and we only included the data from the sites where depth was less than $400 \mathrm{~m}$. More information can be found in Struhsaker (1973).

Regarding both the PIFSC-BotCam and UH-BotCam programs, only deployments that were annotated for all species were used in this study. All observations were identified to the highest taxonomic levels by fish experts in each respective program. We quality controlled and corrected taxonomic names based on current taxonomic status (Chave \& Mundy 1994, Mundy 2005, FishBase [www.fishbase.org], WoRMS [www.marinespecies.org]).

Each survey method had its own spatial and temporal extent and limitations. For example, camera programs and the majority of submersible surveys were conducted during daylight hours and therefore likely underrepresented (or entirely missed) the mesopelagic scattering layer that vertically migrates at night from $>400 \mathrm{~m}$ depths up to $23 \mathrm{~m}$ (Benoit-Bird \& Au 2006). However, representative species of these vertical migrations (e.g. Myctophidae) were captured in night-time trawl surveys and some submersible surveys. Submersibles covered the most extensive area, with a typical survey length of $\sim 3 \mathrm{~km}$, encompassing a variety of seafloor types. Both the BRUVS and BotCam surveys can potentially attract fishes from a wider area than the video frame (Harvey et al. 2007) and might capture fish species attracted to bait disproportionally compared to the other programs, e.g. predatory eels or wide-ranging, large-bodied, roving predatory species (sharks). The temporal extent of the survey data ranged from just a few years (trawls and BRUVS surveys) to almost $30 \mathrm{yr}$ (UH-HURL). Even though the trawl surveys were conducted about 30 yr prior to the other surveys, these surveys targeted soft bottom and included night-time data. Thus the trawl survey data augment the other survey data to give us a better understanding of the entire fish communities. In order to construct the most complete representation of fish communities possible, we merged all datasets into a comprehensive 'large dataset.' We used the encounter/non-encounter data from the entire dataset for the community structure analysis to characterize species composition in relation to 
depth zones. In contrast, we employed only the BotCam data for fitting general additive models (GAMs) and subsequently generating relative biomass maps, as the BotCam data were collected using the same method and could be georeferenced with the recently developed habitat maps. We used the MaxN data for these analyses and species-specific average length data from the PIFSC-BotCam surveys and Hawai'i-specific literature (Pyle et al. 2016). If no species-specific length data were available, we used half of the maximum lengths reported in FishBase (see Section 2.6).

\subsection{Study species and functional groups}

The information in the large dataset included location (deployment latitude and longitude for the camera surveys, starting latitude and longitude for the submersible and trawl surveys), actual recorded depth, depth binned in $10 \mathrm{~m}$ increments, observed species and family names, and data source. The data archive incorporated 24686 observations for 523 identified fish taxa (some observations were only identified to the genus or family level). Phylum, subphylum, or unidentified classifications (e.g. 'teleosts,' 'Actinopterygii,' 'unidentified fish,' 'none') were excluded from analyses. We assigned each species to a functional group (Table 2; for additional details see Tables S1.1 and S1.2 in Supplement S1), based on diet, foraging behavior, life history traits (e.g. growth rate, maximum age), and depth preferences, partly based on the results of the community structure analysis (see Section 2.4).

\subsection{Data analyses: community structure analysis on encounter/non-encounter data}

To examine reef-fish assemblages between 30 and $410 \mathrm{~m}$ depth, we used the 'vegan' and 'clustsig' community ecology packages in $\mathrm{R}$ version 3.6.0 (R Core Team 2017) for all multivariate analyses. Several observations, particularly for fishes in deeper habi-

Table 2. Functional groups represented in the main Hawaiian Islands 'Atlantis' ecosystem model that are considered in this study, and a brief description of the groups with some example species

\begin{tabular}{|c|c|c|c|}
\hline Category & $\begin{array}{l}\text { Functional } \\
\text { group code }\end{array}$ & Description (example species) & References \\
\hline $\begin{array}{l}\text { Mesophotic and subphotic } \\
\text { benthic piscivores }\end{array}$ & MBP & $\begin{array}{l}\text { Benthic or benthopelagic piscivores (eel, } \\
\text { scorpionfish, frogfish, greeneyes, beardfish) }\end{array}$ & $\begin{array}{l}\text { Gartner et al. (1997), Bradley et } \\
\text { al. (2016), Drazen \& Sutton (2017) }\end{array}$ \\
\hline Mesophotic fish & $\begin{array}{l}\text { MBC } \\
\text { MPL }\end{array}$ & $\begin{array}{l}\text { Benthic carnivores (wrasse, goatfish, } \\
\text { flounder, perch) } \\
\text { Planktivores (anthias, flame wrasse, chromis, } \\
\text { butterflyfish) }\end{array}$ & $\begin{array}{l}\text { Dee \& Parrish (1994), Gartner } \\
\text { et al. (1997), Bradley et al. (2016) }\end{array}$ \\
\hline Subphotic fish & $\begin{array}{l}\text { SBC } \\
\text { SPL }\end{array}$ & $\begin{array}{l}\text { Benthic carnivores (rattail, cardinalfish, } \\
\text { orange rakefish) } \\
\text { Planktivores (spikefish, boarfish, armorhead, } \\
\text { slopefish) }\end{array}$ & $\begin{array}{l}\text { Gartner et al. (1997), Drazen \& } \\
\text { Sutton (2017) }\end{array}$ \\
\hline \multirow[t]{2}{*}{ Bottomfish (Deep-7) } & BFW & $\begin{array}{l}\text { Deepwater snappers mostly foraging in water } \\
\text { column above hard-bottom substrate: } \\
\text { opakapaka, onaga, kalekale, lehi } \\
\text { (part of the Deep-7) }\end{array}$ & $\begin{array}{l}\text { Haight et al. (1993), DeMartini } \\
\text { et al. (1996), C. Kelley } \\
\text { (unpubl. data) }\end{array}$ \\
\hline & UKU & $\begin{array}{l}\text { Deepwater snappers mostly foraging on or } \\
\text { near the hard-bottom substrate: ehu, gindai } \\
\text { and } 1 \text { grouper: hapu'upu'u (part of the Deep-7) } \\
\text { Generalist snapper: uku Aprion virescens } \\
\text { (often in similar habitat as the Deep-7) }\end{array}$ & \\
\hline Prey fish & SHP & $\begin{array}{l}\text { Shallow-water prey fish mackerel scad, } \\
\text { bigeye scad }\end{array}$ & $\begin{array}{l}\text { Dalzell et al. (1996), Weng \& } \\
\text { Sibert (2004) }\end{array}$ \\
\hline Coastal pelagics & $\begin{array}{l}\text { PIS } \\
\text { SHR } \\
\text { IRY } \\
\text { RAY }\end{array}$ & $\begin{array}{l}\text { Roving piscivores (jacks, barracudas, } \\
\text { cutlassfishes) } \\
\text { Sharks } \\
\text { Invertivorous rays (sting rays) } \\
\text { Manta ray }\end{array}$ & $\begin{array}{l}\text { Humphreys \& Kramer (1984), } \\
\text { Meyer et al. (2001), Papastamatiou } \\
\text { et al. (2015), Leigh et al. (2017) }\end{array}$ \\
\hline Micronekton & MSL & $\begin{array}{l}\text { Mesopelagic scatter layer: planktivorous } \\
\text { micronekton (myctophids) }\end{array}$ & Benoit-Bird et al. (2001) \\
\hline
\end{tabular}


tats, were only identified to family level. For some families (e.g. Ophichthidae, Myctophidae, and Macrouridae), the functional role of species is similar, there are not that many species in the family, or the bulk of observations come from rather narrow depth ranges (e.g. 324-400 m for Ophichthidae, with 1 observation at $217 \mathrm{~m}$ ). Thus, observations for these families represent important information about fish communities within specific depth ranges. In contrast, for other families, observations at the family level occurred across nearly the entire depth range (e.g. 60-400 m for Carangidae) or are speciose and included a wide range of functional groups (e.g. Labridae, which include grazers, benthic carnivores, and piscivores). Thus, observations for these families would tend to obscure meaningful differences in fish community structure along depth gradients. Therefore, we decided to exclude family-level observations of 3 speciose and widely distributed families, i.e. Lutjanidae (snappers), Carangidae (jacks), and Labridae (wrasses), from the community structure analysis. Community structure was examined at the species/ taxon level using the Bray-Curtis dissimilarity metric (Bray \& Curtis 1957) based on encounter/nonencounter data for $10 \mathrm{~m}$ depth bins (MacLeod et al. 2008). This approach was adopted because the survey methods considered in this study were different so that not all samples had the same probability of encountering every species. We used a complete linkage clustering algorithm, which maximizes distance between clusters, and were interested in a dissimilarity index of at least $67 \%$. A hierarchical cluster dendrogram and non-metric multidimensional scaling (NMDS) ordination (Clarke et al. 2008) were employed to visualize the community structure along the depth bins. Analysis of similarity profiles (SIMPROF, with alpha $=10^{-7}$; Clarke et al. 2008) was used to identify the number of significantly distinct depth zones. Permutational multivariate ANOVA using distance matrices (PERMANOVA; Anderson 2017) was used to confirm the statistical significance of the $a$ posteriori defined depth zones. To assess which species/taxa contributed the most to the Bray-Curtis dissimilarity matrix, we calculated similarity percentages (SIMPER). SIMPER reveal the contribution of species/taxa to the overall Bray-Curtis dissimilarity through pairwise comparisons of depth zones.

\subsection{Seafloor and productivity metrics}

The physical character and geomorphology of the seafloor (morphology and composition) around the
MHI has been described using multibeam echosounder data (MBES - bathymetry and backscatter), and here we employed a range of seafloor metrics developed by Dove et al. (2019). Based on the hypothesis that benthic abundance and biodiversity are correlated with seafloor characteristics (McArthur et al. 2010), Dove et al. (2019) derived several morphological metrics around the MHI that reflect seafloor complexity (e.g. providing greater surface area, habitat, and shelter to marine organisms). The authors also developed classifications of substrate composition, where 'hard' seafloor generally provides a more stable substrate that is more conducive for settlement of benthic sessile organisms. The seafloor morphology metrics derived from the bathymetry (water depth) data included slope, standard deviation (SD; a measure of rugosity), and relative distance to the mean value $(\mathrm{RDMV}$; a measure of relative bathymetric highs and lows). These derivatives were included with backscatter data (a proxy for seafloor hardness and texture) within an unsupervised model to predict substrate composition (i.e. 'hard' or 'soft'). Due to the scarcity of optical validation data, 3 alternative maps were selected that predict variable proportions of 'hard' vs. 'soft,' where each map was subjectively determined to be feasible according to visual assessment of the bathymetry and backscatter, together with the available validation data. Three alternative maps were produced by setting different class membership thresholds (i.e. 2, 4, and 7 classes) within the unsupervised model.

Metrics relating to seafloor orientation, referred to as 'aspect,' were also derived from the bathymetric data, as they can provide a proxy for hydrodynamic conditions, which independently affect habitat distribution and character (but cannot be measured at such fine resolutions) (Roberts et al. 2009). Here, we used northness and eastness, which describe the degree to which the seafloor slopes toward the north or east, capturing different directional components from local currents. Importantly, we incorporated all morphological metrics at 3 spatial resolutions (25, 125 , and $625 \mathrm{~m}$ ), as marine organisms likely respond to seafloor characteristics at varying spatial scales (Wilson et al. 2007) (Table 3).

In addition to geomorphological metrics, we considered a productivity metric, surface chlorophyll a (chl a) concentration. Aqua MODIS monthly 0.0125degree surface chl a concentration estimates for the period 2010-2016 were downloaded (Simons 2017), from which we calculated the mean annual surface chl a concentration (in $\mathrm{mg} \mathrm{m}^{-3}$ ) for each of the $500 \times$ $500 \mathrm{~m}$ grid cells covering the entire MHI region. 
Table 3. Environmental variables used in the generalized additive models to predict the probability of encounter and relative biomass of fish functional groups around the main Hawaiian Islands

\begin{tabular}{|c|c|c|}
\hline Variable & Unit & Description \\
\hline Bathymetry & Meters (m) & Bottom depth \\
\hline Slope & Degrees & Inclination of sea floor (available at 3 spatial resolutions) \\
\hline Standard deviation (SD) & Meters (m) & Measure of rugosity (available at 3 spatial resolutions) \\
\hline $\begin{array}{l}\text { Relative distance to the } \\
\text { mean value (RDMV) }\end{array}$ & Unitless & $\begin{array}{l}\text { Measure of relative position, which identifies highs (positive values) and lows } \\
\text { (negative values) (available at } 3 \text { spatial resolutions) }\end{array}$ \\
\hline Backscatter data & Decibels $(\mathrm{dB})$ & Proxy for seafloor hardness and texture (available at 3 spatial resolutions) \\
\hline Hard or soft & Unitless & $\begin{array}{l}\text { Substrate composition, where thresholds between 'hard' and 'soft' were determined } \\
\text { subjectively through } 3 \text { alternative classifications: } 2,4 \text {, and } 7 \text { classes }\end{array}$ \\
\hline Northness & Radians & $\begin{array}{l}\text { Component of aspect that informs on the orientation of the slope, i.e. its deviation } \\
\text { from north. This metric ranges between -1 (fully south) and } 1 \text { (fully north) and is } \\
\text { available at } 3 \text { spatial resolutions }\end{array}$ \\
\hline Eastness & Radians & $\begin{array}{l}\text { Component of aspect that informs on the orientation of the slope, i.e. its deviation } \\
\text { from east. This metric ranges between }-1 \text { (fully west) and } 1 \text { (fully east) and is } \\
\text { available at } 3 \text { spatial resolutions }\end{array}$ \\
\hline Chlorophyll a & $\mathrm{mg} \mathrm{m}^{-3}$ & $\begin{array}{l}\text { Measure of productivity at the sea surface (satellite-derived monthly values from } \\
2010-2016 \text { ). Mean annual values of this metric per grid cell were used in analyses }\end{array}$ \\
\hline
\end{tabular}

\subsection{Data analyses: GAMs fitted to MaxN data and relative biomass maps}

For this part of the study, we considered only the BotCam surveys conducted by the PIFSC and UH (Table 1), as the sampling methods of these programs were similar, their data were georeferenced and covered a large portion of the MHI region (Fig. 2), and each of the 2 programs had more than 300 survey locations (340 and 896, respectively). To be able to produce relative biomass maps for the 14 fish functional groups listed in Table 2, we proceeded in 7 steps.

First, we produced a $500 \times 500 \mathrm{~m}$ spatial grid for the $\mathrm{MHI}$, integrating environmental parameter values for each of the functional groups using the approach of Grüss et al. (2018a). From the survey data and literature, we determined the depth ranges of the functional groups. Then, from the $500 \times 500 \mathrm{~m}$ spatial grid for the MHI, the environmental data used in this study and the estimated depth ranges of the functional groups, we created a prediction grid integrating environmental parameter values for each of the functional groups (Grüss et al. 2018b).

Second, we generated data input files using observational data. We extracted georeferenced encounter/ non-encounter and non-zero MaxN estimates for all species from the 2 BotCam survey datasets. We multiplied the MaxN values with species-specific mean weights based on mean species length and the relationship: weight $=a \times$ length $^{b}$, with $a$ and $b$ obtained from FishBase. We then aggregated species into functional groups (Table 2) to get the relative bio- mass for each functional group taking into account the relative contribution of the large and small species (and subsequently disparate biomass estimates) in each functional group. In ArcGIS, we assigned environmental parameter values (Table 3) to each of the data points. We deleted records with missing data in any of the survey and environmental variables.

Third, we evaluated the degree of collinearity between continuous environmental covariates (Dormann et al. 2013) and estimated Pearson's correlation coefficients. We discarded 1 of the 2 continuous environmental covariates for which we found a pairwise correlation exceeding 0.7 in absolute value (Leathwick et al. 2006, Dormann et al. 2013).

Fourth, using the 'mgcv' package in the R environment (Wood 2006), we fitted binomial and gamma GAMs to the survey and environmental data for each of the 14 functional groups (Table 2) as follows:

$$
\begin{aligned}
g(\eta)= & s\left(x_{1}\right)+s\left(x_{2}\right)+\ldots+s\left(x_{n}\right)+\text { factor }(H S)+ \\
& \text { factor }(\text { program })+\text { factor }(\text { year })
\end{aligned}
$$

where $\eta$ is either the probability of encounter when given binomial response data, or an estimate of relative biomass when given non-0 abundance data; $g$ represents the link function between $\eta$ and each covariate (logit in the case of the binomial GAMs, and $\log$ in the case of the gamma GAMs); $s$ is a thin-plate regression spline fitted to a given environmental covariate; $x_{1}, x_{2}, \ldots x_{\mathrm{n}}$ are the continuous environmental covariates selected after the collinearity analysis; and $H S$ is the hard/soft factor. Survey program and year are 'nuisance' variables treated as fixed effect 
factors (Grüss et al. 2018a,b). We employed thinplate regression splines with shrinkage and limited each thin-plate regression spline to 4 degrees of freedom to help preserve the ecological interpretability of the functional relationships estimated by GAMs (Grüss et al. 2018a). We used a shrinkage approach to select environmental covariates for the GAMs. After model fitting, if a p-value for an environmental covariate was greater than 0.05 , we removed the environmental covariate from the GAM and refitted it (Grüss et al. 2014, Chagaris et al. 2015). We employed the restricted maximum likelihood (REML) optimization method (Wood 2011). For each of the 14 functional groups, we fitted 9 binomial and gamma GAMs: 3 binomial and gamma GAMs integrating geomorphological data at the 25,125 , or $625 \mathrm{~m}$ resolution combined with 3 levels of hard/soft factors (i.e. $2-, 4-$, or 7-class membership thresholds). We then retained the binomial GAM and the gamma GAM that explained the greatest proportion of deviance in the encounter/non-encounter and relative biomass data, respectively, for further analyses.

Fifth, for each fish functional group, we combined the predictions made by the selected binomial GAM and those made by the selected gamma GAM using the delta method (Lo et al. 1992), and we then evaluated the resulting delta GAM using bootstraps and Spearman's correlation coefficients (Spearman's rho, $\rho)$ between predicted and observed relative biomass values. It was not possible to split the data into test and validation datasets due to a scarcity of relative biomass data for some functional groups. We therefore proceeded as per Grüss et al. (2014) and implemented a validation method employing the datasets internal to GAM development where observed and predicted density values could be compared. From these datasets of observed and predicted relative biomasses, 1000 bootstrap datasets were produced by resampling with replacement within the range of observed and predicted relative biomasses. Spearman's $\rho$ between the relative biomass values predicted by delta GAMs and those observed in monitoring datasets were then estimated and tested to be significantly $(\mathrm{p}<0.05)$ different from 0 .

Sixth, after GAM validation, we assessed the relative importance of covariates in the spatial patterns of probability of encounter and relative biomass of the fish functional groups. To do so, we compared the predictions of the binomial and gamma GAMs fitted as described above ('full GAMs') with the predictions of GAMs after randomization of a given predictor, i.e. after random permutation of the values of a given predictor within the observational dataset ('random
GAMs; ' Thuiller et al. 2012). One minus the Pearson's correlation coefficient between the predictions of the full GAM and the predictions of a random GAM gives an indication of the relative importance of a given predictor in explaining the probability of encounter or relative biomass of a functional group.

Finally, we generated $500 \times 500 \mathrm{~m}$ relative biomass maps for the fish functional groups, using the fitted delta GAMs and the $500 \times 500 \mathrm{~m}$ prediction grid constructed in the first step.

\section{RESULTS}

\subsection{Identification of distinct faunal depth zones between 30 and $410 \mathrm{~m}$ depth}

Our large dataset comprised 24005 identifiable observations for 124 families and 523 species/genera (Fig. 3, and Fig. S2.1 in Supplement 2). The majority of these observations came from the UH-HURL submarine surveys, especially for the 300-410 m depth zone where encounters for BotCam surveys were limited due to the low ambient light levels (Fig. 3). In general, there were broad overlaps between UHHURL family encounters and family encounters by other survey programs (Fig. 3).

The hierarchical cluster and SIMPROF analyses ( $p<0.001)$ identified 2 to 10 distinct depth zones based on faunal breaks with dissimilarity values ranging between 99 and $40 \%$ (Fig. 4). Two larger clusters were considerably more distinct (99\% dissimilarity) compared to the interior clusters. These 2 clusters ranged from 30-129 m and 130-410 m, indicating that the largest faunal difference occurred between these 2 depth zones. Based on this result, we redefined the mesophotic zone as the zone between 30 and $129 \mathrm{~m}$. Mesophotic faunal breaks were also detected at $60 \mathrm{~m} \mathrm{(72 \%} \mathrm{dissimilarity)} \mathrm{and} 90 \mathrm{~m}$ (48\% dissimilarity). Interestingly, the second highest dissimilarity value (89\%) across the entire depth range, revealed a faunal break at $239 \mathrm{~m}_{\text {; }}$ this result suggests a stronger difference in species composition between the 130-239 $\mathrm{m}$ and $240-410 \mathrm{~m}$ depth ranges compared to faunal breaks at 170 and $320 \mathrm{~m}$ in the subphotic zone (Figs. 4 \& 5). Using a dissimilarity index of $68 \%$ as our lower limit for clustering, we identified 6 distinct depth zones. Since, to our knowledge, there is no official classification for subphotic depth zones, we: (1) drew inspiration from the terminology of Baldwin et al. (2018) and used the term 'rariphotic' for the zones where depth ranges between 130 and $320 \mathrm{~m}$; and (2) referred to Watling et al. 


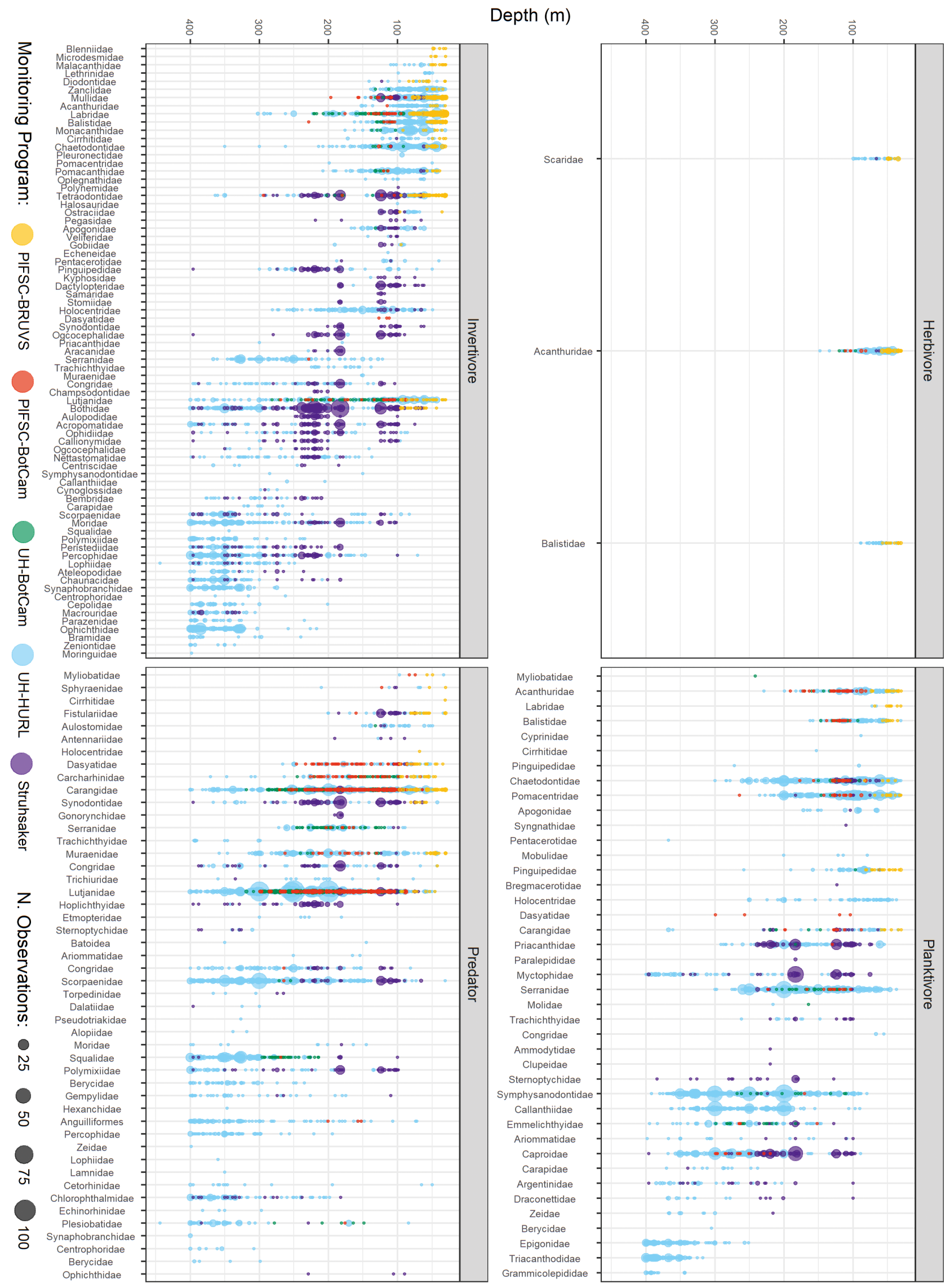

Fig. 3. Fish family encounters by depth for each of the survey programs considered in this study. See Table 1 for definitions of abbreviations and additional information on the programs 
Fig. 4. Hierarchical cluster dendrogram using Bray-Curtis dissimilarity analysis of fish taxa encounters/non-encounters between 30 and $410 \mathrm{~m}$ depth around the main Hawaiian Islands. Different colors distinguish between depth groups that have significantly $\left(\mathrm{p}<10^{-7}\right)$ distinct faunal communities based on the analysis of similarity profiles (SIMPROF analysis). The values on the $x$-axis represent $10 \mathrm{~m}$ depth intervals (e.g. 30 refers to the $30-39.9 \mathrm{~m}$ depth interval)

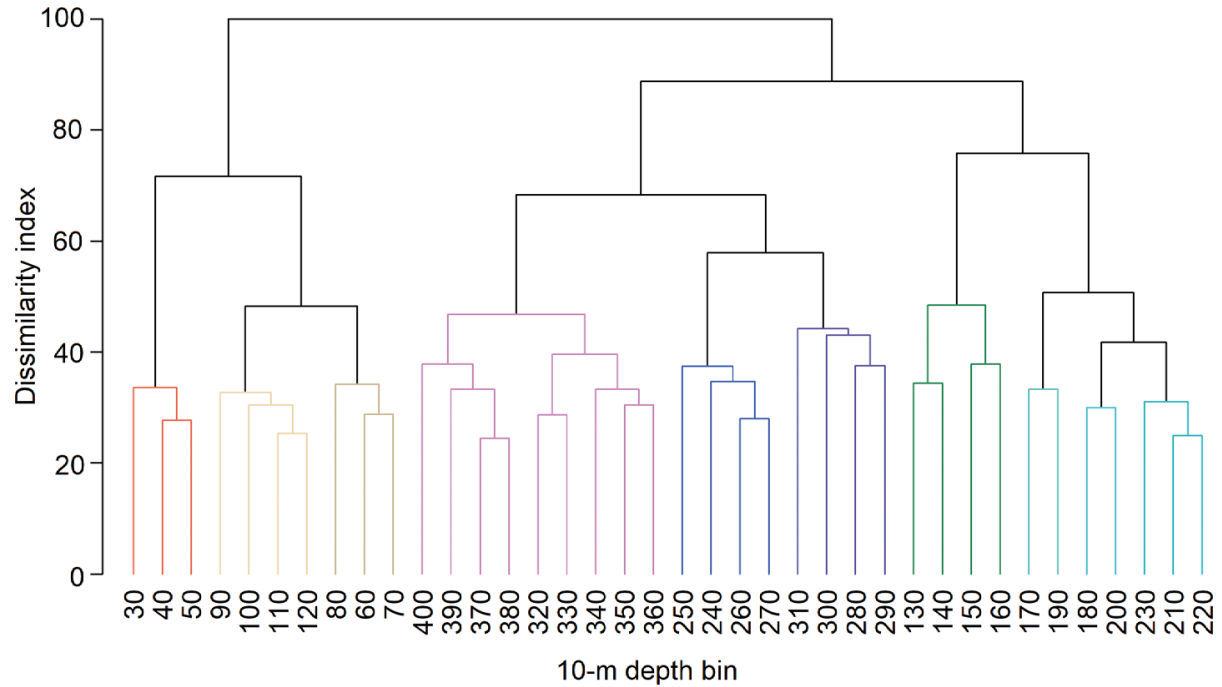

matrix. For example, the top 14 taxa contributed to just $10 \%$ of the dissimilarity between the upper and lower mesophotic zone with a similar number of taxa contributing to the dissimilarities between the other depth zones (Table 4). Some species extended throughout the mesophotic zone, whereas others were present throughout the extensive subphotic zone (Figs. S2.2-S2.7). However, clear distinctions in fish assemblages were found when considering prevalent species in the mesophotic, rariphotic, and bathyal zones (Fig. 6). In the upper mesophotic zone (30-59 m), the introduced bluestriped snapper Lutjanus kasmira and millet butterflyfish Chaetodon miliaris were most prevalent (Fig. 6). Going deeper to the lower mesophotic zone (60-129 m), 3-spot chromis Chromis verater, as well as blue-striped snapper and millet butterflyfish,
There were no clear taxa responsible for the divisions between 2 successive depth zones, as many species contributed $1 \%$ or less to the dissimilarity

\subsection{Taxonomic composition of fish assemblages varies with depth}

Fig. 5. Non-metric multidimensional scaling (NMDS) ordination plot of faunal breaks along $10 \mathrm{~m}$ depth bins using a priori depth zones generated from hierarchical clustering. Colors represent distinct faunal depth zones. The values on the plot represent $10 \mathrm{~m}$ depth intervals (e.g. 30 refers to the 30-39 m depth interval). The dark grey areas on the plot encompass the entire mesophotic (30-129 m) and subphotic (130-410 m) zones

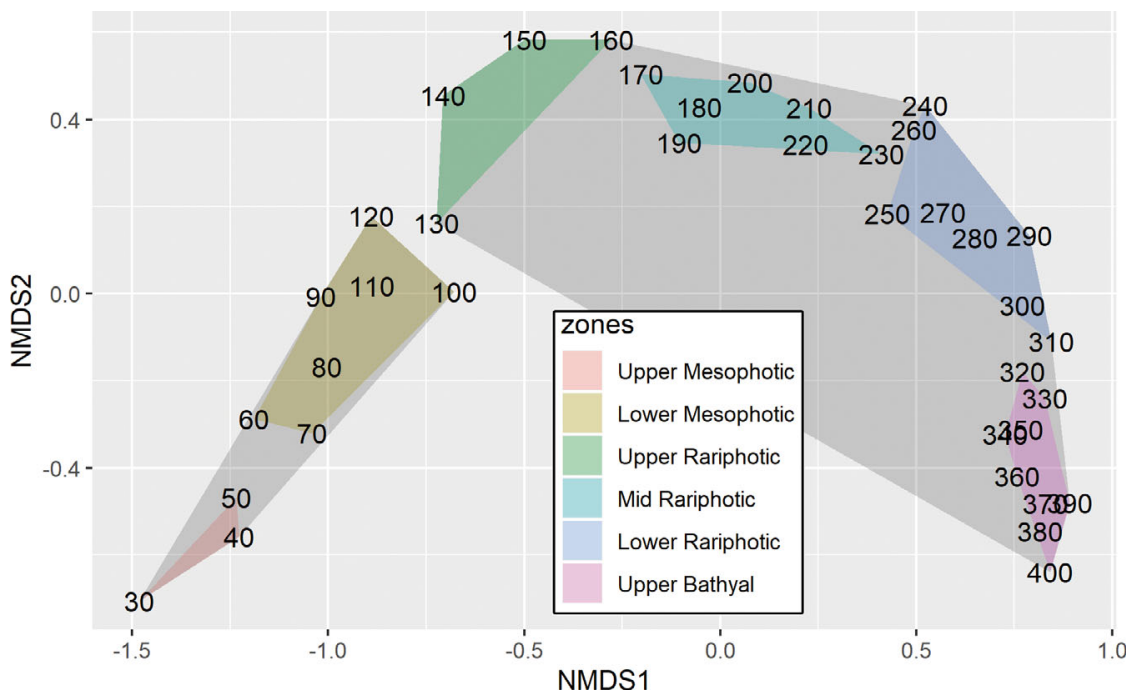


Table 4. Top 10 taxa that contribute to dissimilarity between depth zones according to similarity percentages (SIMPER). Taxon names are in bold if they dominated in the shallower depth zone of the 2 depth zones that were compared. The depth zones considered included the upper mesophotic (30-59 m), lower mesophotic (60-129 m), upper rariphotic (130-169 m), midrariphotic (170-239 m), lower rariphotic (240-319 m), and upper bathyal (320-410 m) zones

\begin{tabular}{|lll|}
\hline Upper vs. lower mesophotic & Lower mesophotic vs. upper rariphotic & Upper vs. mid-rariphotic \\
\hline Canthigaster rivulata & Balistidae & Antigonia spp. \\
Gunnellichthys spp. & Canthigaster coronata & Chlorophthalmus proridens \\
Gymnothorax flavimarginatus & Chromis spp. & Hoplichthys citrinus \\
Gymnothorax undulatus & Lactoria diaphana & Kentrocapros aculeatus \\
Lactoria diaphana & Naso brevirostris & Pristipomoides auricilla \\
Naso maculatus & Parupeneus chrysonemus & Torquigener florealis \\
Paracirrhites arcatus & Parupeneus porphyreus & Grammatonotus laysanus \\
Seriola spp. & Torquigener florealis & Neoniphon aurolineatus \\
Xanthichthys spp. & Xanthichthys spp. & Antigonia steindachneri \\
Thalassoma duperrey & Acanthurus spp. & Bodianus bathycapros \\
& & \\
Mid- vs. lower rariphotic & Lower rariphotic vs. upper bathyal & \\
\hline Bodianus bathycapros & Hollardia goslinei & \\
Dasyatidae & Macrouridae & \\
Kentrocapros aculeatus & Synagrops argyreus & \\
Ariosoma marginatum & Gymnothorax nuttingi & \\
Carcharhinus plumbeus & Odontanthias elizabethae & \\
Priacanthus alalaua & Pristipomoides sieboldii & \\
Priacanthus meeki & Roa excelsa & \\
Pseudanthias fucinus & Coelorinchus spilonotus & \\
Aulotrachichthys heptalepis & Parapercis roseoviridis & \\
Halieutaea retifera & Polymixia spp. & \\
\hline
\end{tabular}

were most commonly observed (Fig. 6). In the upper rariphotic zone (130-169 $\mathrm{m})$, a planktivorous species, the Hawaiian deep anthias Odontanthias fuscipinnis, and a piscivorous species, greater amberjack Seriola dumerili, were particularly prevalent. The most commonly encountered species in the mid-rariphotic zone (170-239 m) were slope fishes Symphysanodon maunaloae, followed by long-tail red snapper Etelis coruscans (known locally as 'onaga,' a species of the Deep-7 complex), greater amberjack, and the planktivorous splendid perches (Grammatonotus spp.). The lower rariphotic zone (240-319 m) also had observations of schools of slope fishes and a high prevalence of short-tail red snapper E. carbunculus (another species of the Deep-7 complex, locally known as 'ehu'). Smallbodied boarfishes (Antigonia spp.) were also commonly observed in the lower rariphotic zone. Lastly, in the upper bathyal zone (320-410 m), schools of slope fishes were still observed. However, some unusual species were spotted in this very deep zone, but not in the other depth zones, such as Hawaiian spikefish Hollardia goslinei, shortspine spurdog Squalus mitsukurii, and many eel or eellike species (e.g. cutthroat eel Meadia abyssalis, cusk eels [Ophichthidae]) (Fig. S2.7).

\subsection{Spatial predictions of relative biomass}

Planktivorous rays (included in the RAY group), invertivorous rays (IRY group), and species commonly associated with the mesopelagic scatter layer (MSL group) were rarely encountered by the camera surveys considered in this study. Therefore, we were unable to develop GAMs for these 3 functional groups and focused on 11 of the 14 original functional groups. Pearson's correlation coefficient between the slope and SD metrics varied between 0.98 and 0.99 for all functional groups. Preliminary analyses revealed that slope had a stronger effect on the probability of encounter and relative biomass of functional groups than SD. Therefore, we dropped the SD metric from the analyses. The delta GAMs of 10 functional groups passed the validation test $(\mathrm{p}<0.05$; Table 5); hence, for 10 groups, it was reasonable to employ delta GAM predictions to generate relative biomass maps, but not for the shark group. It should be noted that model skill was low (Spearman's correlation coefficient: <0.30) for almost half of these groups.

In general, spatial patterns of probability of encounter were best explained by depth, followed by slope (Table 6; Supplement 3). Exceptions were: (1) the meso-and subphotic benthic piscivore (MBP) 


\section{Depth zone}

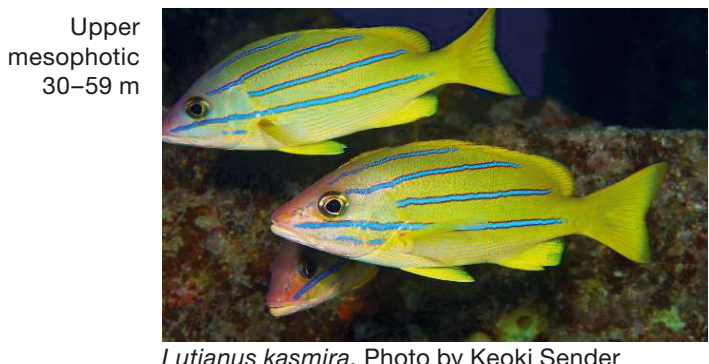

Lutjanus kasmira. Photo by Keoki Sender www.marinelifephotography.com

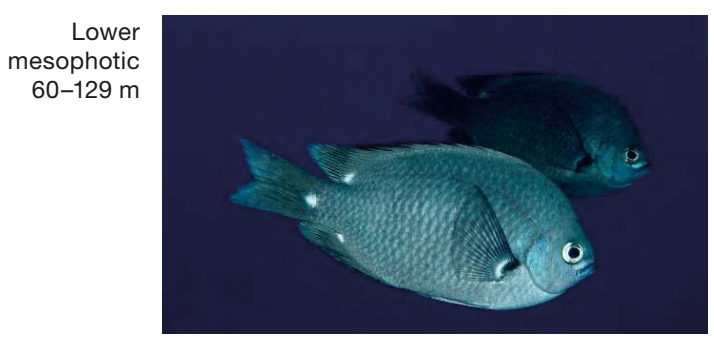

Chromis verater. Photo by Keoki Sender www.marinelifephotography.com

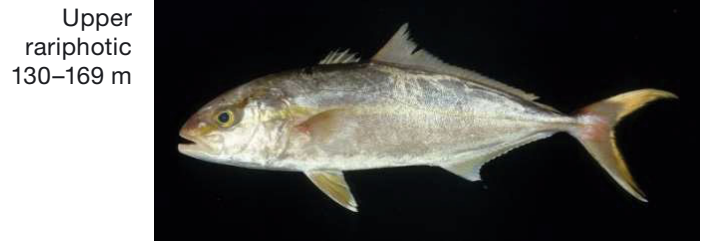

Seriola dumerili. Photo by Mike Seki, NOAA-PIFSC

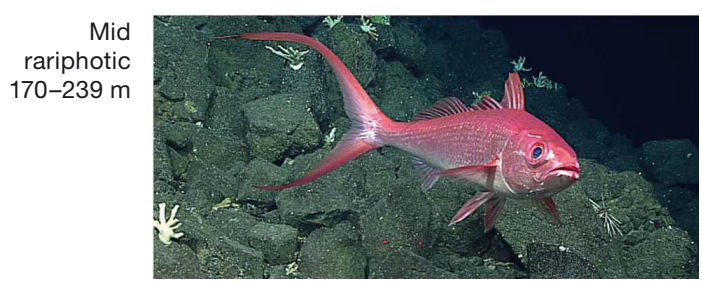

Etelis coruscans. Photo by HURL

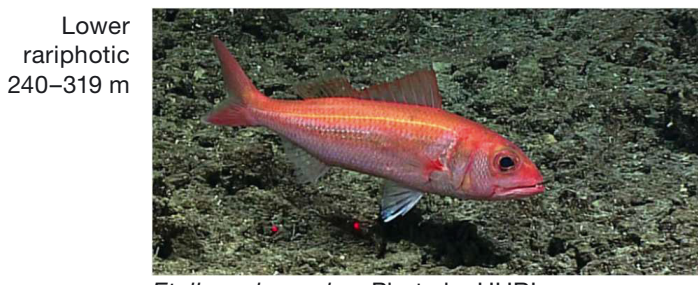

Etelis carbunculus. Photo by HURL

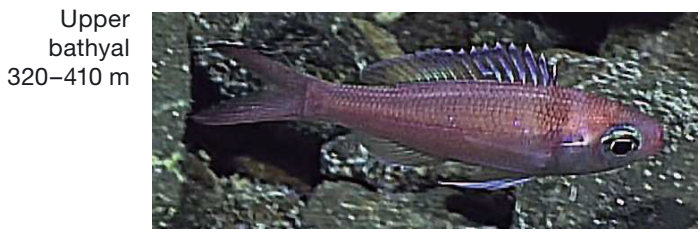

Symphysanodon maunaloae. Photo by NOAA Office of Ocean Exploration and Research

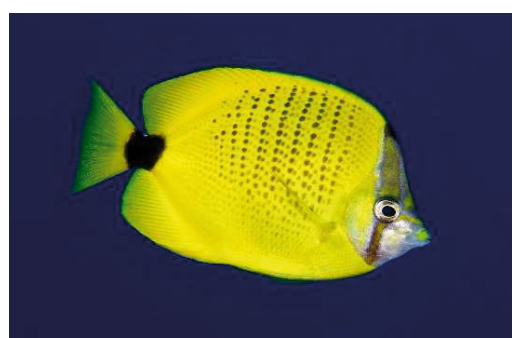

Chaetodon miliaris. Photo by Keoki Sender www.marinelifephotography.com

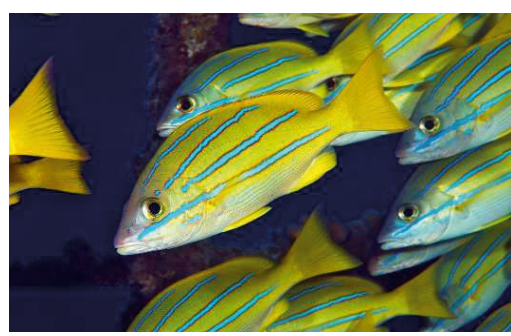

Lutjanus kasmira. Photo by Keoki Sender www.marinelifephotography.com

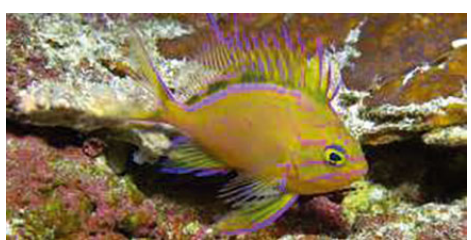

Odontanthias fuscipinnis. Photo by Bishop Museum
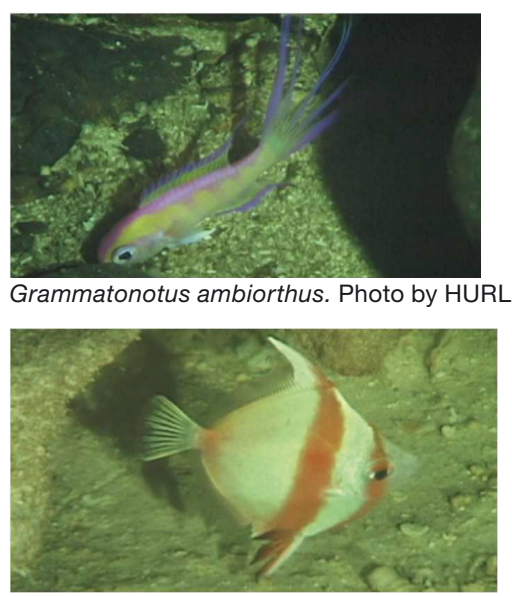

Antigonia eos. Photo by HURL

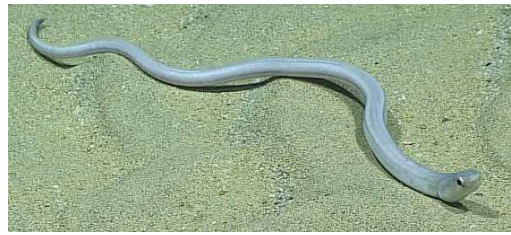

Ophichthidae. Photo by NOAA Office of Ocean Exploration and Research

Fig. 6. Examples of prevalent fish species found in the 6 different depth zones along the 30-410 m depth gradient around the main Hawaiian Islands. PIFSC: Pacific Islands Fisheries Science Center; HURL: Hawai'i Underwater Research Laboratory 
Table 5. Results of the validation test performed on the delta generalized additive models of the 11 functional groups for which there were sufficient survey data. Shown are the median Spearman's correlation coefficients (rho) between observed and predicted relative biomasses, their 95\% confidence intervals ( $\mathrm{CI}$, inf: inferior and sup: superior), and p-values. Example species for functional groups are provided in Table 2, and the complete list of species composing each functional group is given in Table S1.2 in Supplement 1

\begin{tabular}{|lcccc|}
\hline Functional group & $\mathrm{Rho}$ & $\mathrm{CI}_{\text {inf }}$ & $\mathrm{CI}_{\text {sup }}$ & $\mathrm{p}$ \\
\hline Mesophotic benthic carnivores & 0.35 & 0.31 & 0.41 & $<0.0001$ \\
Mesophotic planktivores & 0.33 & 0.29 & 0.38 & $<0.0001$ \\
Bottomfish-bottom & 0.46 & 0.41 & 0.51 & $<0.0001$ \\
Bottomfish-water column & 0.48 & 0.42 & 0.34 & $<0.0001$ \\
Uku & 0.34 & 0.30 & 0.40 & $<0.0001$ \\
Subphotic benthic carnivores & 0.20 & 0.14 & 0.26 & $<0.0001$ \\
Subphotic planktivores & 0.26 & 0.20 & 0.32 & $<0.0001$ \\
Prey fishes & 0.10 & 0.04 & 0.15 & 0.0033 \\
Meso-and subphotic benthic & 0.18 & 0.13 & 0.25 & $<0.0001$ \\
piscivores & & & & \\
Sharks & 0.01 & 0.0 & 0.08 & 0.71 \\
Roving piscivores & 0.50 & 0.45 & 0.55 & $<0.0001$ \\
\hline
\end{tabular}

group, for which substrate type (2-level hard/soft factor) was the most influential environmental covariate; and (2) the bottomfish group that forages in the water column (BFW), for which backscatter at the $125 \mathrm{~m}$ resolution was the most influential covariate. For most functional groups, spatial patterns of relative biomass were best explained by ridge-like features (RDMV) or depth (Table 6; Figs S3.1-S3.10 in Supplement 3).

Integrating a combination of geomorphological covariates at different spatial resolutions and defining alternative hard/soft classifications was important for predicting the spatial patterns of probability of encounter and relative biomass of the different functional groups (Table 6; Supplement 3). For example, the hard/soft substrate factor was retained in the binomial GAM of most benthopelagic groups (exceptions were MBC and UKU; Fig. 7, Table 6), while this factor was not retained in the binomial GAM of planktivore groups (MPL, SPL, SHP; Supplement 3). However, substrate was an important predictor of the relative biomass of planktivore groups (Fig. 7, Table 6).

Oceanographic conditions captured by proxy through the northness and eastness metrics were important predictors of the relative biomass of various functional groups: BFW, BFB, MBC, PIS, UKU, and SPL (Fig. 8). Noteworthy is that the spatial scale of these predictor variables that was retained varied from one functional group to another (Fig. 8).

After the delta GAMs were fitted and validated (Table 5), we used their predictions to produce relative biomass maps at $500 \times 500 \mathrm{~m}$ resolution (Fig. 9). We focused on the roving piscivores (PIS group) and the BFW group here and zoom in on a specific area (Penguin Bank) so that individual spatial grid cells are visible. For the same groups, we also show relative biomass maps for the whole study area (Fig. 10). Relative biomass maps for each of the functional groups are provided in Supplement 4. Our predictions suggest that both functional groups are most prevalent at the center of the MHI chain (darker polygons in Fig. 10), with the bottomfish group being more abundant at deeper depths. The center of the MHI chain was also a biomass hotspot for most other

Table 6. Environmental predictors retained in the binomial (b) and gamma ( $\mathrm{g}$ ) models for each functional group (column headings; see Table 2 for group definitions). Substrate was modeled at 3 classes of refinement (indicated by $2 \mathrm{cl}, 4 \mathrm{cl}$, and $7 \mathrm{cl}$ ); the class at which substrate was retained is noted in the table. All other predictor variables except chlorophyll $a$ (chl $a$, where an ' $x$ ' indicates it was retained) were included at 3 spatial resolutions $(25,125$, and $625 \mathrm{~m})$, the spatial resolution at which this variable was retained is included in the table. Bold indicates highest relative importance among the environmental predictors

\begin{tabular}{|c|c|c|c|c|c|c|c|c|c|c|c|}
\hline & & MBP & $\mathrm{MBC}$ & MPL & $\mathrm{SBC}$ & SPL & BFW & $\mathrm{BFB}$ & UKU & SHP & PIS \\
\hline Depth & $\begin{array}{l}\mathrm{b} \\
\mathrm{g}\end{array}$ & & $\begin{array}{l}25 \mathrm{~m} \\
25 \mathrm{~m}\end{array}$ & $25 \mathrm{~m}$ & & $25 \mathrm{~m}$ & & $\begin{array}{c}25 \mathrm{~m} \\
125 \mathrm{~m}\end{array}$ & $25 \mathrm{~m}$ & $25 \mathrm{~m}$ & $\begin{array}{c}\mathbf{2 5 m} \\
125 \mathrm{~m}\end{array}$ \\
\hline Slope & $\begin{array}{l}\mathrm{b} \\
\mathrm{g}\end{array}$ & $125 \mathrm{~m}$ & $\begin{array}{l}25 \mathrm{~m} \\
25 \mathrm{~m}\end{array}$ & $25 \mathrm{~m}$ & $125 \mathrm{~m}$ & $25 \mathrm{~m}$ & $125 \mathrm{~m}$ & & $125 \mathrm{~m}$ & $25 \mathrm{~m}$ & $25 \mathrm{~m}$ \\
\hline RDMV & $\begin{array}{l}\mathrm{b} \\
\mathrm{g}\end{array}$ & & & $125 \mathrm{~m}$ & $\begin{array}{c}125 \mathrm{~m} \\
\mathbf{2 5 m}\end{array}$ & & $125 \mathrm{~m}$ & & $125 \mathrm{~m}$ & $25 \mathrm{~m}$ & $125 \mathrm{~m}$ \\
\hline Backscatter & $\begin{array}{l}\mathrm{b} \\
\mathrm{g}\end{array}$ & & & & $125 \mathrm{~m}$ & $25 \mathrm{~m}$ & $125 \mathrm{~m}$ & $\begin{array}{c}25 \mathrm{~m} \\
125 \mathrm{~m}\end{array}$ & $25 \mathrm{~m}$ & & \\
\hline Substrate & $\begin{array}{l}\mathrm{b} \\
\mathrm{g}\end{array}$ & $\begin{array}{l}2 \mathrm{cl} \\
2 \mathrm{cl}\end{array}$ & & $4 \mathrm{cl}$ & $\begin{array}{l}7 \mathrm{cl} \\
4 \mathrm{cl}\end{array}$ & $7 \mathrm{cl}$ & $7 \mathrm{cl}$ & $4 \mathrm{cl}$ & & $7 \mathrm{cl}$ & $7 \mathrm{cl}$ \\
\hline Northness & $\begin{array}{l}\mathrm{b} \\
\mathrm{g}\end{array}$ & $625 \mathrm{~m}$ & & & & $25 \mathrm{~m}$ & $125 \mathrm{~m}$ & $125 \mathrm{~m}$ & $125 \mathrm{~m}$ & & $\begin{array}{c}25 \mathrm{~m} \\
125 \mathrm{~m}\end{array}$ \\
\hline Eastness & $\begin{array}{l}\mathrm{b} \\
\mathrm{g}\end{array}$ & $625 \mathrm{~m}$ & $25 \mathrm{~m}$ & & & & & & & $25 \mathrm{~m}$ & \\
\hline Chl a & $\begin{array}{l}\mathrm{b} \\
\mathrm{g}\end{array}$ & & $\mathrm{x}$ & $\mathrm{x}$ & & & $\begin{array}{l}x \\
x\end{array}$ & & & & \\
\hline
\end{tabular}



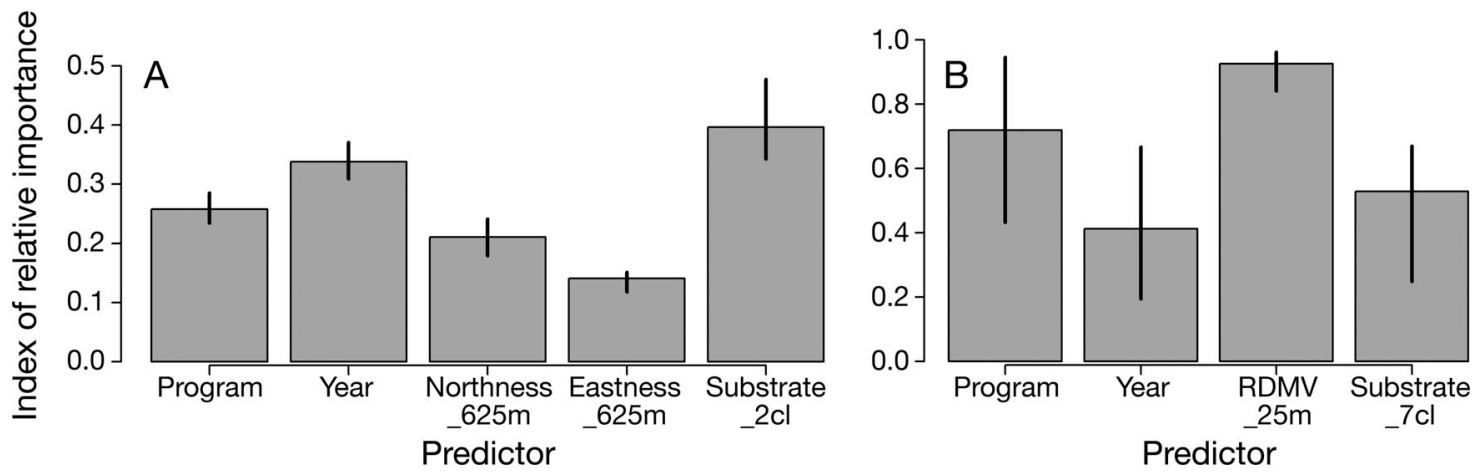

Fig. 7. Relative importance of environmental predictors (see Table 3 for descriptions of environmental variables) and the fixed effects of survey program and year in the spatial patterns of (A) probability of encounter of the meso-and subphotic benthic piscivore (MBP) group and (B) relative biomass of the prey fish (SHP) group (see Table 2 for functional group definitions). Vertical black lines indicate $95 \%$ confidence intervals

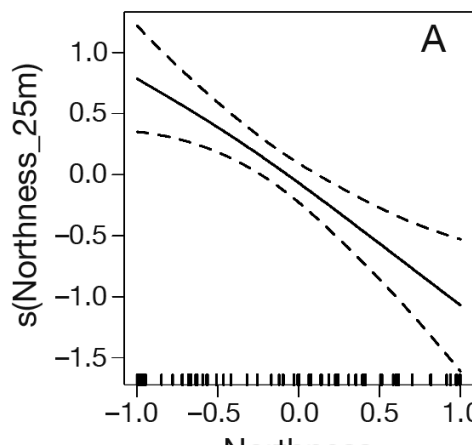

Northness

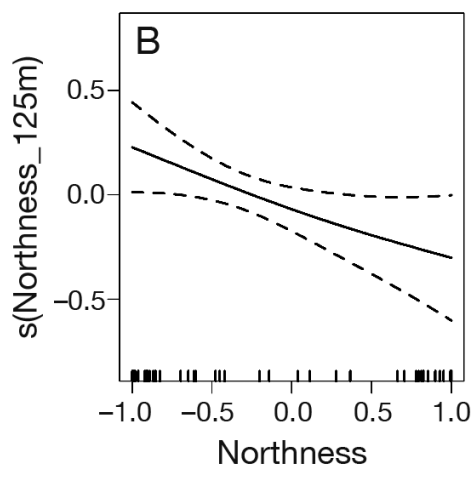

Fig. 8. Smoothed curves of the additive effect of northness to the estimated relative biomass of (A) the subphotic planktivore (SPL) group and (B) the UKU group (see Table 2 for functional group definitions) when northness is considered at (A) $25 \mathrm{~m}$ resolution and (B) $125 \mathrm{~m}$ resolution. Dotted lines represent $95 \%$ confidence intervals, while each mark along the $x$-axis represents a single observation. The values on the $x$-axis inform on the orientation of the slope, i.e. its deviation from north; northness ranges between -1 (fully south) and 1 (fully north)

functional groups (Supplement 4), particularly Penguin Bank (the area on the left hand side of Fig. 9 and the darkest polygon off the southwest coast of Molokai in Fig. 10) for 7 out of the 9 functional groups.

\section{DISCUSSION}

\subsection{Six depth zones host distinct fish assemblages}

Combining different survey datasets allowed us to benefit from a large number of observations to analyze the structure of fish communities in the 30-410 m depth ecosystems of the MHI region. In particular, the HURL program provided unique insights into fish community structure in the upper bathyal (320$410 \mathrm{~m}$ ) depth zone. In general, the mesophotic realm has been described as the zone where depth ranges from 30-150 m (Kahng et al. 2010, Rocha et al. 2018). However, based on the fish faunal break that we identified at $129 \mathrm{~m}$ (with a $99 \%$ Bray-Curtis dissimilarity index), we define the mesophotic zone in the MHI region as the zone where depth ranges between 30 and $129 \mathrm{~m}$. The $130 \mathrm{~m}$ break was also found for the Curaçao region (Baldwin et al. 2018), the Gulf of Mexico (Semmler et al. 2017), and Enewetak, Marshall Islands (Thresher \& Colin 1986). Our results clearly show that the mesophotic zone can be further divided into upper (30-59 m) and lower (60-129 m) mesophotic zones (dissimilarity index of $71.6 \%$ ), corroborating earlier results (Slattery \& Lesser 2012, Bejarano et al. 2014, Asher et al. 2017). Beyond the mesophotic zone, we classified subphotic habitats into 4 subzones characterized by distinct fish communities (dissimilarity index of $68.3 \%$ ), which we named the upper rariphotic zone (130-169 m), the mid-rariphotic zone (170-239 $\mathrm{m})$, the lower rariphotic zone (240-319 m), and the upper bathyal zone (320$410 \mathrm{~m}$ ). Our results contrast with information on community structure in the Gulf of Mexico (Semmler et al. 2017) and Enewetak (Thresher \& Colin 1986), where species composition was considered to be similar between 130 and $300 \mathrm{~m}$. In both the Gulf of Mexico and the Curaçao region, a distinct deep-water faunal break was identified at $190 \mathrm{~m}$ (Semmler et al. 2017, Baldwin et al. 2018), which is slightly shallower than the highly dissimilar (dissimilarity index of $88.8 \%$ ) fish faunal break we found $(240 \mathrm{~m})$. Possibly, the clear waters of the oligotrophic ecosystems around the MHI contribute to light penetration to deeper depths, which could explain the $240 \mathrm{~m}$ deep-water break found in 

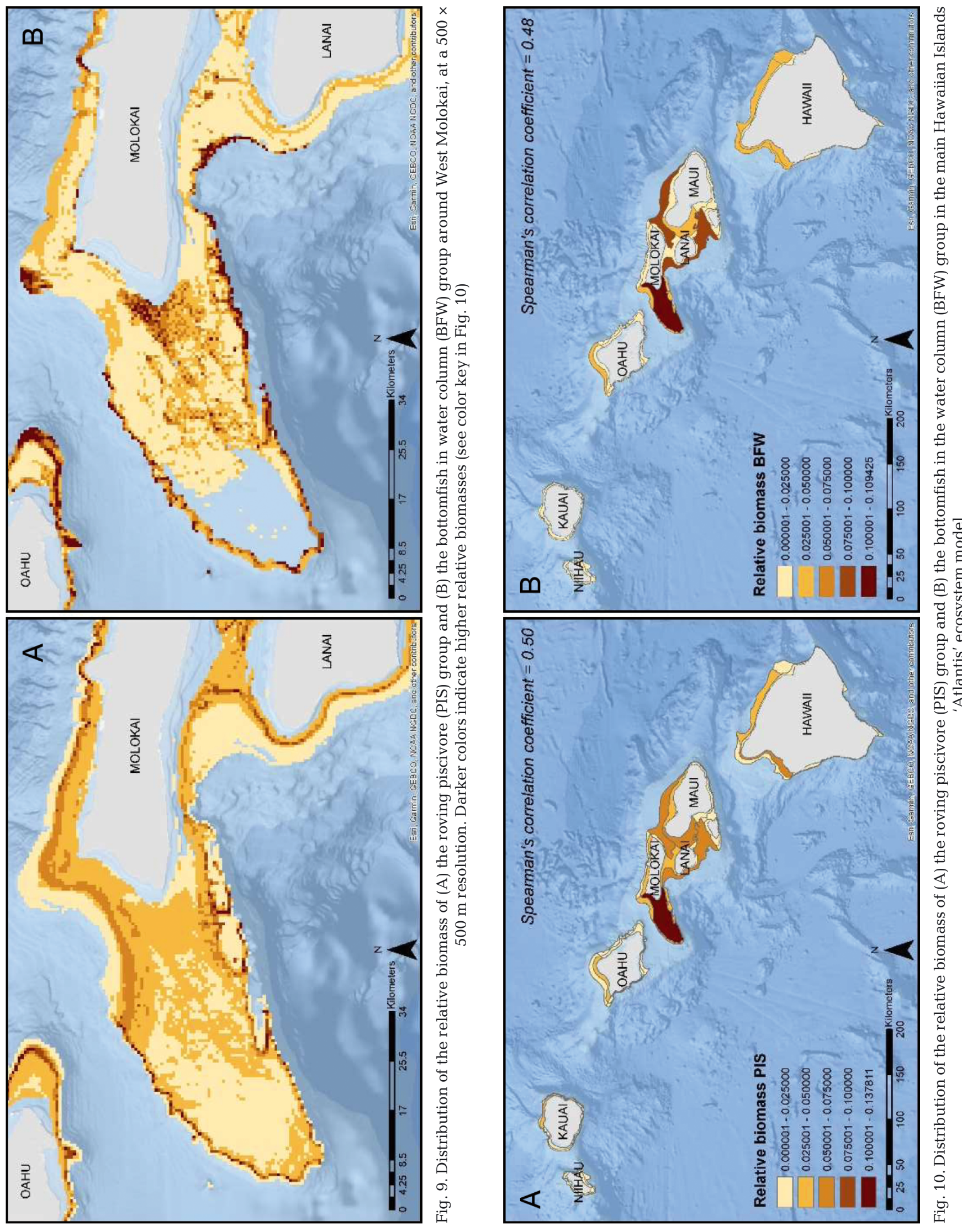
this study. Additionally, Hawaiian waters have a shallow ( 0-100 m) mixed layer with a thermocline extending from approximately 100-600 m depth, at which depth the water temperature is around $6^{\circ} \mathrm{C}$ (Weng \& Block 2004). Moreover, there is a more rapid decrease in temperature and oxygen concentration starting around $250 \mathrm{~m}$ compared to shallower depths (Fig. 1). Depth zonation with restricted species assemblages that occupy specific depth zones is a wellestablished phenomenon (Carney 2005, Yeh \& Drazen 2009); the extensive dataset compiled for this study allowed us to refine and characterize 6 discrete depth zones between 30 and $410 \mathrm{~m}$.

Species composition somewhat overlapped across neighboring depth zones, yet the most commonly encountered species did vary along the depth gradient; thus, benthic carnivores were the most commonly observed functional group in the mesophotic zones, while planktivores and piscivores were the most abundant functional groups in the subphotic zones (Fig. 6). In the upper bathyal zone, many observations from the submarine surveys were not identified to the species level, partly because identification was difficult, but also because some of the species encountered have never been formally identified. Even if the number of studies conducted at mesophotic depths is substantial and increasing, new species are still being discovered at these depths (Pyle et al. 2016, Baldwin et al. 2018), underscoring the importance of further observational and taxonomic studies.

Understanding energy connectivity and trophic dependencies between the 6 identified depth zones is an important avenue for future research to assist EBFM. In general, regional productivity determines deep-water carrying capacity through sinking of surface-derived organic particles or the active transport of food through diel vertical migrations (Siegel \& Deuser 1997, Drazen \& Sutton 2017). Hence, it seems likely that changes in the upper water column will impact deeper-water fish communities. Future studies should focus on the environmental parameters that influence community structures at deeper depths to understand the potential impacts of climate change in deeper waters as well as trophic connections between depth zones.

\subsection{Importance of bathymetry, geomorphology, and spatial resolution as predictors of encounter probability and relative biomass of fish}

Many spatially explicit ecosystem models, such as Atlantis, are highly dependent on distribution maps to simulate spatial patterns of predator-prey interactions (Grüss et al. 2016). To generate these relative biomass maps from GAM predictions for the parameterization of the MHI Atlantis model, we used the baited BotCam datasets and a newly developed substrate characterization scheme (Dove et al. 2019). As might be anticipated, depth, which is associated with various environmental variables (e.g. light, oxygen, and temperature; Fig. 1), was the most influential predictor of probability of encountering fish, followed by slope (which is highly correlated with rugosity), for most functional groups, which corresponds with the results of the cluster analysis that revealed distinct fish assemblages along the depth gradient.

Previous studies on habitat association of the Deep7 bottomfish species in the MHI region also showed that depth and slope were important predictors of encounter probability (Misa et al. 2013, Oyafuso et al. 2017). For example, Oyafuso et al. (2017) showed that apart from depth, ridge-like features, backscatter, and rugosity at a 5 or $60 \mathrm{~m}$ resolution explained most of the deviance in species-specific models. Since we grouped the 7 bottomfish species into 2 functional groups, the BFB group (Deep-7 species associated with the bottom) and the BFW group (Deep-7 species that mostly forage in the water column), depth had less effect on the probability of encounter of the BFW group, as this group encompassed species whose preferred depth ranges between 90 and $400 \mathrm{~m}$. However, in accordance with Oyafuso et al. (2017), we found that ridge-like features (RDMV in this study), rugosity (in our case slope), and backscatter were important predictors of the probability of encountering the BFW group. Additionally, in corroboration with the results of Oyafuso et al. (2017), we found that ridge-like structures at a very fine resolution (5 $\mathrm{m}$ in Oyafuso et al. 2017 and $25 \mathrm{~m}$ in our study) had a relatively large effect on the probability of encountering the BFB group and that ridge-like structures at a lower resolution (60 m in Oyafuso et al. 2017 and $125 \mathrm{~m}$ in our study) had a relatively large effect on the probability of encountering the BFW group.

To our knowledge, no other studies have considered multiple geomorphological parameters at multiple spatial resolutions and alternative definitions of substrate type, in order to improve the accuracy of spatial distribution maps of both meso-and subphotic coral reef ecosystems. We integrated the seafloor metrics at multiple spatial resolutions and alternative definitions of substrate type as environmental covariates into alternative GAMs, under the assumption that different species groups interact with different 
features of the physical seafloor habitat (Costa et al. 2015, Lecours et al. 2016). Considering different definitions of substrate type and seafloor metrics at different spatial resolutions was very influential when modeling the spatial relative biomass patterns of functional groups inhabiting the MHI ecosystems (Table 6 , Supplement 3). However, no particular combination of seafloor metrics (at a specific spatial resolution) was a consistently better predictor of spatial patterns of probability of encounter and relative biomass across all functional groups. For example, the 7level hard/soft factor had a large effect on the probability of encountering the roving piscivore (PIS) group, while the 2-level hard/soft factor had a large influence on the probability of encountering the mesoand subphotic benthic piscivore (MBP) group (Table 6). Another example is that of the binomial GAM of the MBC group, for which depth was retained when the $25 \mathrm{~m}$ spatial resolution was considered, but not when the 125 or $625 \mathrm{~m}$ resolutions were considered. Thus, our assumption that species groups may respond to different features of the seafloor habitat was confirmed, and the sophistication of the geomorphological parameters available for this study allowed us to develop bespoke GAMs that explained a greater proportion of the deviance in the data than many previous GAM studies (e.g. Crec'hriou et al. 2008, Grüss et al. 2019).

\subsection{Penguin Bank and Maui Nui are hotspots of fish biomass}

The relative biomass maps that we generated from GAM predictions suggest that Penguin Bank, located southwest of Moloka'i (Fig. 2), has geomorphological characteristics that are suitable for sustaining relatively high biomasses for most of the fish functional groups inhabiting the meso- and subphotic ecosystems of the MHI region (Supplement 4). The other fish 'hotspots' suggested by our relative biomass maps are Maui Nui and the north coast of Hawai'i. Penguin Bank and Maui Nui have extensive shelfs with substantial hard substrate elevated above sediment deposits, remnants from the sea-level history and associated antecedent topography (Locker et al. 2010). These substrates offer favorable conditions for colonization by benthic organisms (Kahng \& Maragos 2006, Locker et al. 2010, Rooney et al. 2010) that provide habitat for many fish species and mobile invertebrates (Boland \& Parrish 2005, Kahng \& Kelley 2007). For example, Maui Nui and the deep channel between Maui and Hawai'i, the 'Au'au Channel, are known hotspots for the deepwater coral species Leptoseris spp. (Kahng \& Kelley 2007, Pyle et al. 2016) and Penguin Bank for various species of deepwater snappers (Misa et al. 2013).

Before our study, little was known about the spatial patterns of relative biomass of the forage fish (SHP) group at meso-and subphotic depths, despite the ecological and economic importance of that functional group (Weng \& Sibert 2004, Wiley et al. 2015). SHP species are prey for many predatory species, including jacks, tunas, marine mammals, and seabirds, making them an important link in the food web as they channel energy between plankton (their prey) and top predators. SHP species are also sought after by coastal fisheries (Smith 1993). Our study suggests that these forage fish are most abundant at mesophotic depths on Penguin Bank and, to a lesser extent, the northeast coast of Maui (Supplement 4). These areas somewhat match the areas where opelu Decapterus macarellus catch per unit effort (CPUE) was found to be high (Weng \& Sibert 2004), although the highest opelu CPUEs came from the central east coast of Hawai'i. However, because encounter rates were low for opelu, our GAM predictions for this group are not very reliable (Spearman's correlation coefficients $=0.10, p=0.003$; Table 3). Model skill was also low (Spearman's correlation coefficients: $<0.30$ ) for subphotic benthic carnivores, subphotic planktivores, and meso- and subphotic benthic piscivores. In order to improve the relative biomass distribution maps, we recommend that future studies survey the areas around the MHI to refine our understanding of the distribution patterns (including seasonal distribution) of these ecologically and economically important groups. Additionally, we recommend diet studies to increase our understanding of the trophic connections between the shallow reefs and these deeper ecosystems. These data will be extremely helpful for proper parameterization of ecosystem models that can then be used to explore EBFM questions.

\section{CONCLUDING REMARKS}

Meso-and subphotic reef systems have received scientific attention to increase our understanding of commercially important species. However, for an ecosystem-based approach to be operational, understanding species dynamics in relation to oceanographic and ecological processes, habitat, and human marine uses is crucial. Hence, there is a critical need for more insights into fish community structure 
at these depths. We showed that these ecosystems harbor a broad range of fish taxa. By amassing an extensive data set, we identified 6 zones with distinct fish communities in the 30-410 m depth range. Additionally, we produced relative biomass maps for juvenile and adult life stages of fish functional groups combined. Ideally, separate distribution maps should be constructed for the juvenile and adult life stages of some of the fish functional groups considered in this study, as they may inhabit very different habitats, as has been shown for deep-water snapper species (Moffitt \& Parrish 1996, Parrish et al. 1997, Misa et al. 2013). Unfortunately, age information and species-specific information on habitat association are lacking for the majority of the species of the MHI region. Furthermore, the nature of the survey data available for this study did not allow us to distinguish between juveniles and adults. Additionally, when more data become available, seasonal distribution maps for relevant functional groups will also be very informative. Notwithstanding, the relative biomass maps generated in this study represent a valuable achievement, and will enhance the accuracy of simulated predator-prey dynamics, which form the basis of most ecosystem models (Grüss et al. 2018b). If total biomass estimates (e.g. stock assessment model estimates) are available, it will be easy to convert relative biomass estimates into absolute biomasses. The information provided in this study will not only be useful to parameterize ecosystem models, but can also be used for supporting marine spatial planning and other EBFM efforts (e.g. bycatch mitigation plans).

Acknowledgements. We are very grateful to Audrey Rollo, Virginia Moriwake, and Elena Conser for help with data retrieval from the HURL dataset; to Frank Parrish and Ray Boland for sharing their knowledge on deep-water ecology and reviewing a draft version; to Tom Oliver and Courtney Couch for help with R-scripts; to Bruce Mundy for checking the taxonomic names (any omissions are our fault) and supplying pictures; and to Michael Seki, the Bishop Museum, Keoki Sender, Meagan Putts, and the NOAA Office of Ocean Exploration and Research for supplying pictures. Also, thanks to Tom Oliver and 2 anonymous reviewers for their comments, which greatly improved the clarity of our paper. Funding for the UH-BotCam program was provided by the State of Hawai'i Division of Aquatic Resources directly and via the Federal Aid in Sport Fish Restoration program (F17R38-study IX). Funding for the PIFSC-BRUVS program was provided by the NOAA Coral Reef Conservation Program (CRCP Project 381). Funding for the HURL program was provided by the NOAA Office of Ocean Exploration and Research. All funders had no role in the study design, data collection, and analysis, decision to publish, or preparation of this manuscript.

\section{LITERATURE CITED}

Anderson MJ (2017) Permutational multivariate analysis of variance (PERMANOVA). In: Balakrishnan N, Colton $\mathrm{T}$, Everitt B, Piegorsch W, Ruggeri F, Teugels JL (eds) Wiley StatsRef: Statistics Reference Online. https://doi.org/10. 1002/9781118445112.stat07841

Asher J, Williams ID, Harvey ES (2017) Mesophotic depth gradients impact reef fish assemblage composition and functional group partitioning in the Main Hawaiian Islands. Front Mar Sci 4:98

Ault JS, Smith SG, Richards BL, Yau A and others (2018) Towards fishery-independent biomass estimation for Hawaiian Deep 7 bottomfish. Tech Memo NMFS-PIFSC67. NOAA, NMFS, Pacific Islands Fisheries Science Center, Honolulu, HI

*Baldwin CC, Tornabene L, Robertson DR (2018) Below the mesophotic. Sci Rep 8:4920

Bejarano I, Appeldoorn RS, Nemeth M (2014) Fishes associated with mesophotic coral ecosystems in La Parguera, Puerto Rico. Coral Reefs 33:313-328

Benoit-Bird KJ, Au WWL (2003) Prey dynamics affect foraging by a pelagic predator (Stenella longirostris) over a range of spatial and temporal scales. Behav Ecol Sociobiol 53:364-373

Benoit-Bird KJ, Au WWL (2006) Extreme diel horizontal migrations by a tropical nearshore resident micronekton community. Mar Ecol Prog Ser 319:1-14

Benoit-Bird K, Au WWL, Brainard RE, Lammers MO (2001) Diel horizontal migration of the Hawaiian mesopelagic boundary community observed acoustically. Mar Ecol Prog Ser 217:1-14

Boland RC, Parrish FA (2005) A description of fish assemblages in the black coral beds off Lahaina, Maui, Hawai'i. Pac Sci 59:411-420

* Bongaerts P, Ridgway T, Sampayo EM, Hoegh-Guldberg O (2010) Assessing the 'deep reef refugia' hypothesis: focus on Caribbean reefs. Coral Reefs 29:309-327

*Badley CJ, Longenecker K, Pyle RL, Popp BN (2016) Compound-specific isotopic analysis of amino acids reveals dietary changes in mesophotic coral-reef fish. Mar Ecol Prog Ser 558:65-79

Bray JR, Curtis JT (1957) An ordination of the upland forest communities of southern Wisconsin. Ecol Monogr 27: 325-349

Carney RS (2005) Zonation of deep biota on continental margins. Oceanogr Mar Biol Annu Rev 43:211-278

* Chagaris D, Mahmoudi B, Muller-Karger F, Cooper W, Fischer K (2015) Temporal and spatial availability of Atlantic thread herring, Opisthonema oglinum, in relation to oceanographic drivers and fishery landings on the Florida Panhandle. Fish Oceanogr 24:257-273

Chave EH, Mundy BC (1994) Deep-sea benthic fish of the Hawaiian Archipelago, Cross Seamount, and Johnston Atoll. Pac Sci 48:367-409

Clark MR, Rowden AA, Schlacher T, Williams A and others (2010) The ecology of seamounts: structure, function, and human impacts. Annu Rev Mar Sci 2:253-278

Clarke KR, Somerfield PJ, Gorley RN (2008) Testing of null hypotheses in exploratory community analyses: similarity profiles and biota-environmental linkage. J Exp Mar Biol Ecol 366:56-69

C Costa B, Kendall MS, Parrish FA, Rooney J and others (2015) Identifying suitable locations for mesophotic hard corals offshore of Maui, Hawai'i. PLOS ONE 10:e0130285 
Crec'hriou R, Bonhomme P, Criquet G, Cadiou G and others (2008) Spatial patterns and GIS habitat modelling of fish in two French Mediterranean coastal areas. Hydrobiologia 612:135-153

Dalzell P, Adams T, Polunin N (1996) Coastal fisheries in the Pacific Islands. Oceanogr Mar Biol Annu Rev 34:395-531

De'ath G, Fabricius KE, Sweatman H, Puotinen M (2012) The 27-year decline of coral cover on the Great Barrier Reef and its causes. Proc Natl Acad Sci USA 109:17995-17999

Dee AJ, Parrish JD (1994) Reproductive and trophic ecology of the soldierfish Myripristis amaena in tropical fisheries. Fish Bull 92:516-530

DeMartini EE, Parrish FA, Ellis DM (1996) Barotrauma-associated regurgitation of food: implications for diet studies of Hawaiian pink snapper, Pristipomoides filamentosus (family Lutjanidae). Fish Bull 94:250-256

Di Lorenzo E, Schneider N, Cobb KM, Franks PJS and others (2008) North Pacific Gyre Oscillation links ocean climate and ecosystem change. Geophys Res Lett 35: L08607

* Dormann CF, Elith J, Bacher S, Buchmann C and others (2013) Collinearity: a review of methods to deal with it and a simulation study evaluating their performance. Ecography 36:27-46

Dove D, Weijerman M, Grüss A, Acoba T, Smith JR (2019) Substrate mapping to inform ecosystem science and marine spatial planning around the Main Hawaiian Islands. In: Harris P, Baker E (eds) Seafloor geomorphology as benthic habitat. GeoHab Atlas of seafloor geomorphic features and benthic habitat, $2^{\text {nd }}$ edn. Elsevier

Drazen JC, Sutton TT (2017) Dining in the deep: the feeding ecology of deep-sea fishes. Annu Rev Mar Sci 9:337-366

Ellis DM, DeMartini EE (1995) Evaluation of video camera technique for indexing abundances of juvenile pink snapper Pristipomoides filamentosus, and other Hawaiian insular shelf fishes. Fish Bull 93:67-77

Frade PR, Bongaerts P, Englebert N, Rogers A, GonzalezRivero M, Hoegh-Guldberg O (2018) Deep reefs of the Great Barrier Reef offer limited thermal refuge during mass coral bleaching. Nat Commun 9:3447

Fukunaga A, Kosaki RK, Wagner D, Kane C (2016) Structure of mesophotic reef fish assemblages in the northwestern Hawaiian Islands. PLOS ONE 11:e0157861

Fulton EA, Smith ADM, Johnson CR (2004) Biogeochemical marine ecosystem models I: IGBEM - a model of marine bay ecosystems. Ecol Model 174:267-307

Fulton EA, Smith ADMM, Smith DC, Johnson P (2014) An integrated approach is needed for ecosystem based fisheries management: insights from ecosystem-level management strategy evaluation. PLOS ONE 9:e84242

Gartner JV Jr, Crabtree RE, Sulak KJ (1997) Feeding at depth. In: Randall D, Farrell A (eds) Deep-sea fishes. Academic Press, San Diego, CA, p 115-193

Gloeckler K, Choy CA, Hannides CCS, Close HG, Goetze E, Popp BN, Drazen JC (2018) Stable isotope analysis of micronekton around Hawaii reveals suspended particles are an important nutritional source in the lower mesopelagic and upper bathypelagic zones. Limnol Oceanogr 63:1168-1180

* Grüss A, Drexler M, Ainsworth CH (2014) Using delta generalized additive models to produce distribution maps for spatially explicit ecosystem models. Fish Res 159:11-24

Grüss A, Babcock EA, Sagarese SR, Drexler M and others (2016) Improving the spatial allocation of functional group biomasses in spatially-explicit ecosystem models: insights from there Gulf of Mexico models. Bull Mar Sci 92:473-496

* Grüss A, Rose KA, Simons J, Ainsworth $\mathrm{CH}$ and others (2017) Recommendations on the use of ecosystem modeling for informing ecosystem-based fisheries management and restoration outcomes in the Gulf of Mexico. Mar Coast Fish 9:281-295

Grüss A, Chagaris DD, Babcock EA, Tarnecki JH (2018a) Assisting ecosystem-based fisheries management efforts using a comprehensive survey database, a large environmental database, and generalized additive models. Mar Coast Fish 10:40-70

Grüss A, Drexler MD, Ainsworth CH, Babcock EA, Tarnecki JH, Love MS (2018b) Producing distribution maps for a spatially-explicit ecosystem model using large monitoring and environmental databases and a combination of interpolation and extrapolation. Front Mar Sci 5:16

G Güss A, Drexler MD, Chancellor E, Ainsworth CH and others (2019) Representing species distributions in spatiallyexplicit ecosystem models from presence-only data. Fish Res 210:89-105

Gullestad P, Abotnes AM, Bakke G, Skern-Mauritzen M, Nedreaas K, Søvik G (2017) Towards ecosystem-based fisheries management in Norway-practical tools for keeping track of relevant issues and prioritising management efforts. Mar Policy 77:104-110

* Haight WR, Parrish JD, Hayes TA (1993) Feeding ecology of deepwater lutjanid snappers at Penguin Bank, Hawaii. Trans Am Fish Soc 122:328-347

* Harvey ES, Cappo M, Butler JJ, Hall N, Kendrick GA (2007) Bait attraction affects the performance of remote underwater video stations in assessment of demersal fish community structure. Mar Ecol Prog Ser 350:245-254

*Harvey CJ, Kelble CR, Schwing FB (2017) Implementing 'the IEA': using integrated ecosystem assessment frameworks, programs, and applications in support of operationalizing ecosystem-based management. ICES J Mar Sci 74:398-405

Humphreys RL, Kramer SH (1984) Ciguatera and the feeding habits of the greater amberjack, Seriola dumerili, in the Hawaiian Archipelago. In: Grigg RW, Tanoue KY (eds) Proceedings of the $2^{\text {nd }}$ Symposium on Resource Investigations in the Northwestern Hawaiian Islands. University of Hawai'i, Honolulu, HI, p 179-191

Kahng SE, Kelley CD (2007) Vertical zonation of megabenthic taxa on a deep photosynthetic reef (50-140 m) in the Au'au Channel, Hawaii. Coral Reefs 26:679-687

Kahng SE, Maragos JE (2006) The deepest, zooxanthellate scleractinian corals in the world? Coral Reefs 25:254

KKahng SE, Garcia-Sais JR, Spalding HL, Brokovich E and others (2010) Community ecology of mesophotic coral reef ecosystems. Coral Reefs 29:255-275

Kaplan IC, Burden M, Levin PS, Fulton EA (2010) Fishing catch shares in the face of global change: a framework for integrating cumulative impacts and single species management. Can J Fish Aquat Sci 67:1968-1982

次 Leathwick JR, Elith J, Hastie T (2006) Comparative performance of generalized additive models and multivariate adaptive regression splines for statistical modelling of species distributions. Ecol Model 199:188-196

Lecours V, Dolan MFJ, Micallef A, Lucieer VL (2016) A review of marine geomorphometry, the quantitative study of the seafloor. Hydrol Earth Syst Sci 20:3207-3244

* Leigh SC, Papastamatiou Y, German DP (2017) The nutritional physiology of sharks. Rev Fish Biol Fish 27:561-585 
Lindfield SJ, McIlwain JL, Harvey ES (2014) Depth refuge and the impacts of SCUBA spearfishing on coral reef fishes. PLOS ONE 9:e92628

Link JS, Browman HI (2014) Integrating what? Levels of marine ecosystem-based assessment and management. ICES J Mar Sci 71:1170-1173

Lo NC, Jacobson LD, Squire JL (1992) Indices of relative abundance from fish spotter data based on delta-lognormal models. Can J Fish Aquat Sci 49:2515-2526

Locker SD, Armstrong RA, Battista TA, Rooney JJ, Sherman C, Zawada DG (2010) Geomorphology of mesophotic coral ecosystems: current perspectives on morphology, distribution, and mapping strategies. Coral Reefs 29: 329-345

MacLeod C, Mandleberg L, Schweder C, Bannon S, Pierce G (2008) A comparison of approaches for the modelling the occurrence of marine animals. Hydrobiologia 612:21-32

McArthur MA, Brooke BP, Przeslawski R, Ryan DA and others (2010) On the use of abiotic surrogates to describe marine benthic biodiversity. Estuar Coast Shelf Sci 88: 21-32

Merritt D, Donovan MK, Kelley C, Waterhouse L, Parke M, Wong K, Drazen JC (2011) BotCam: a baited camera system for nonextractive monitoring of bottomfish species. Fish Bull 109:56-67

Meyer CG, Holland KN, Wetherbee BM, Lowe CG (2001) Diet, resource partitioning and gear vulnerability of Hawaiian jacks captured in fishing tournaments. Fish Res 53:105-113

Misa WFXE, Drazen JC, Kelley CD, Moriwake VN (2013) Establishing species-habitat associations for 4 eteline snappers with the use of a baited stereo-video camera system. Fish Bull 111:293-308

Moffitt RB, Parrish FA (1996) Habitat and life history of juvenile Hawaiian pink snapper, Pristipomoides filamentosus. Pac Sci 50:371-381

Moore CH, Drazen JC, Kelley CD, Misa WFXE (2013) Deepwater marine protected areas of the main Hawaiian Islands: establishing baselines for commercially valuable bottomfish populations. Mar Ecol Prog Ser 476:167-183

Mundy BC (2005) Checklist of the fishes of the Hawaiian Archipelago. Bishop Mus Bull Zool 6:1-704

Nelson E, Mendoza G, Regetz J, Polasky S and others (2009) Modeling multiple ecosystem services, biodiversity conservation, commodity production, and tradeoffs at landscape scales. Front Ecol Environ 7:4-11

* Oyafuso ZS, Drazen C, Moore CH, Franklin EC (2017) Habitat-based species distribution modelling of the Hawaiian deepwater snapper-grouper complex. Fish Res 195: $19-27$

Papastamatiou YP, Meyer CG, Kosaki RK, Wallsgrove NJ, Popp BN (2015) Movements and foraging of predators associated with mesophotic coral reefs and their potential for linking ecological habitats. Mar Ecol Prog Ser 521:155-170

Parrish FA (2006) Precious corals and subphotic fish assemblages. Atoll Res Bull 543:425-438

Parrish FA, DeMartini EE, Ellis DM (1997) Nursery habitat in relation to production of juvenile pink snapper, Pristipomoides filamentosus, in the Hawaiian Archipelago. Fish Bull 95:137-148

Pereira PHC, Macedo CH, Nunes JACC, Marangoni LFB, Bianchini A (2018) Effects of depth on reef fish communities: insights of a 'deep refuge hypothesis' from Southwestern Atlantic reefs. PLOS ONE 13:e0203072
Pikitch EK, Santora C, Babcock EA, Bakun A and others (2004) Ecosystem-based fishery management. Science 305:346-347

Plagányi ÉE (2007) Models for an ecosystem approach to fisheries. FAO Fish Tech Pap 477. FAO, Rome

Pyle RL, Boland R, Bolick H, Bowen BW and others (2016) A comprehensive investigation of mesophotic coral ecosystems in the Hawaiian Archipelago. PeerJ 4:e2475

R Core Team (2017) R: a language and environment for statistical computing. R Foundation for Statistical Computing, Vienna

Richards BL, Smith SG, Ault JS, DiNardo GT and others (2016) Design and implementation of a bottomfish fishery-independent survey in the Main Hawaiian Islands. Tech Memo NMFS-PIFSC-53. NOAA, NMFS, Pacific Islands Fisheries Science Center, Honolulu, HI

* Roberts JM, Davies AJ, Henry LA, Dodds LA and others (2009) Mingulay reef complex: an interdisciplinary study of cold-water coral habitat, hydrography and biodiversity. Mar Ecol Prog Ser 397:139-151

* Rocha LA, Pinheiro HT, Shepherd B, Papastamatiou YP, Luiz OJ, Pyle RL, Bongaerts P (2018) Mesophotic coral ecosystems are threatened and ecologically distinct from shallow water reefs. Science 361:281-284

* Rooney J, Donham E, Montgomery A, Spalding H and others (2010) Mesophotic coral ecosystems in the Hawaiian Archipelago. Coral Reefs 29:361-367

* Sackett DK, Drazen JC, Moriwake VN, Kelley CD, Schumacher BD, Misa WFXE (2014) Marine protected areas for deepwater fish populations: an evaluation of their effects in Hawai'i. Mar Biol 161:411-425

* Semmler RF, Hoot WC, Reaka ML (2017) Are mesophotic coral ecosystems distinct communities and can they serve as refugia for shallow reefs? Coral Reefs 36: 433-444

Siegel DA, Deuser WG (1997) Trajectories of sinking particles in the Sargasso Sea: modeling of statistical funnels above deep-ocean sediment traps. Deep Sea Res I 44: 1519-1541

Simons RA (2017) ERDDAP. NOAA/NMFS/SWFSC/ERD, Monterey, CA. https://coastwatch.pfeg.noaa.gov/erddap

Slattery M, Lesser MP (2012) Mesophotic coral reefs: a global model of community structure and function. In: Yellowlees D, Hughes TP (eds) Proc $12^{\text {th }}$ Int Coral Reef Symp, Cairns, Australia, 9-13 July 2012

Smith MK (1993) An ecological perspective on inshore fisheries in the main Hawaiian Islands. Mar Fish Rev 55: 34-49

Steinberg DK, Cope JS, Wilson SE, Kobari T (2008) A comparison of mesopelagic mesozooplankton community structure in the subtropical and subarctic North Pacific Ocean. Deep-Sea Res II 55:1615-1635

Struhsaker P (1973) A contribution to the systematics and ecology of Hawaiian bathyal fishes. PhD dissertation, University of Hawaii at Manoa, Honolulu, HI

Thresher RE, Colin PL (1986) Trophic structure, diversity and abundance of fishes of the deep reef $(30-300 \mathrm{~m})$ at Enewetak, Marshall Islands. Bull Mar Sci 38:253-272

Thuiller W, Lafourcade B, Araujo M (2012) The presentation manual for BIOMOD. Laboratoire d'Ecologie Alpine, Université Joseph Fourier, Grenoble

Vetter EW, Smith CR, De Leo FC (2010) Hawaiian hotspots: enhanced megafaunal abundance and diversity in submarine canyons on the oceanic islands of Hawaii. Mar Ecol 31:183-199 
Watling L, Guinotte J, Clark MR, Smith CR (2013) A proposed biogeography of the deep ocean floor. Prog Oceanogr 111:91-112

Weijerman M, Fulton EA, Janssen ABG, Kuiper JJ and others (2015) How models can support ecosystem-based management of coral reefs. Prog Oceanogr 138:559-570

Weijerman M, Grace-McCaskey C, Grafeld SL, Kotowicz DM, Oleson KLL, van Putten IE (2016) Towards an ecosystem-based approach of Guam's coral reefs: the human dimension. Mar Policy 63:8-17

Weijerman M, Robinson S, Parrish F, Polovina J, Littnan C (2017) Comparative application of trophic ecosystem models to evaluate drivers of endangered Hawaiian monk seal populations. Mar Ecol Prog Ser 582:215-229

Weng KC Block BA (2004) Diel vertical migration of the bigeye thresher shark (Alopias superciliosus), a species possessing orbital retia mirabilia. Fish Bull 102:221-9

Weng KCM, Sibert JR (2004) Analysis of the fisheries for two pelagic carangids in Hawaii. SOEST 00-04, JIMAR 00-332.

Editorial responsibility: Myron Peck,

Hamburg, Germany
University of Hawaii, Joint Institute for Marine and Atmospheric Research, Honolulu, Hawaii

Wiley J, Sabater M, Walker R, Miller K (2015) Characterization of the akule fishery in the island of Oahu, Hawaii: potential utility of aerial spotter data to enhance fishery information. Western Pacific Regional Fishery Management Council, Honolulu, HI

* Wilson MFJ, O'Connell B, Brown C, Guinan JC, Grehan AJ (2007) Multiscale terrain analysis of multibeam bathymetry data for habitat mapping on the Continental Slope. Mar Geod 30:3-35

Wood SN (2006) Generalized additive models: an introduction with R. Chapman and Hall/CRC, Boca Raton, FL

*Wood SN (2011) Fast stable restricted maximum likelihood and marginal likelihood estimation of semiparametric generalized linear models. R Stat Soc B Stat Methodol 73:3-36

*Yeh J, Drazen JC (2009) Depth zonation and bathymetric trends of deep-sea megafaunal scavengers of the Hawaiian Islands. Deep Sea Res I 56:251-266

Submitted: April 16, 2019; Accepted: September 9, 2019

Proofs received from author(s): October 25, 2019 